\title{
Excess of Serotonin (5-HT) Alters the Segregation of Ispilateral and Contralateral Retinal Projections in Monoamine Oxidase A Knock- Out Mice: Possible Role of 5-HT Uptake in Retinal Ganglion Cells During Development
}

\author{
A. L. Upton, ${ }^{1}$ N. Salichon, ${ }^{2}$ C. Lebrand, ${ }^{1}$ A. Ravary, ${ }^{1}$ R. Blakely, ${ }^{3}$ I. Seif, ${ }^{2}$ and P. Gaspar ${ }^{1}$ \\ 1/nstitut National de la Santé et de la Recherche Médicale U106, Hôpital de la Salpêtrière, 75651 Paris cedex 13, France, \\ 2Unité Mixte de Recherche 146, Institut Curie, 91405 Orsay, France, and ${ }^{3}$ Department of Pharmacology, Vanderbilt \\ University, Nashville, Tennessee 37212
}

Retinal ganglion cell (RGCs) project to the ipsilateral and contralateral sides of the brain in the dorsal lateral geniculate nucleus (dLGN) and the superior colliculus (SC). Projections from both eyes are initially intermingled until postnatal day 3 (P3) but segregate into eye-specific layers by P8. We report that this segregation does not occur in monoamine oxidase $A$ knock-out mice (MAOA-KO) that have elevated brain levels of serotonin (5-HT) and noradrenaline. The abnormal development of retinal projections can be reversed by inhibiting 5-HT synthesis from P0 to P15. We found that in MAOA-KO mice, 5-HT accumulates in a subpopulation of RGCs and axons during embryonic and early postnatal development. The RGCs do not synthesize $5-\mathrm{HT}$ but reuptake the amine from the extracellular space. In both MAOA-KO and normal mice, high-affinity uptake of 5-HT and serotonin transporter (SERT) immunoreactivity are observed in retinal axons from the optic cup to retinal terminal fields in the SC and dLGN. In the dLGN, transient SERT labeling corresponds predominantly to the ipsilateral retinal projection fields. We show that, in addition to SERT, developing RGCs also transiently express the vesicular monoamine transporter gene VMAT2: thus, retinal axons could store 5-HT in synaptic vesicles and possibly use it as a borrowed neurotransmitter. Finally we show that the $5-\mathrm{HT}-1 \mathrm{~B}$ receptor gene is expressed by RGCs throughout the retina from E15 until adult life. Activation of this receptor is known, from previous studies, to reduce retinotectal activity; thus $5-\mathrm{HT}$ in excess could inhibit activity-dependent segregation mechanisms. A hypothesis is proposed whereby, during normal development, localized SERT expression could confer specific neurotransmission properties on a subset of RGCs and could be important in the fine-tuning of retinal projections.

Key words: retinal ganglion cell; axon pruning; development; dorsal lateral geniculate; superior colliculus; monoamine oxidase; serotonin transporter; vesicular monoamine transporter; $5-H T_{1 B}$ receptor
In all mammals, there is a partial crossing of the retinal projections to the visual centers that contain a binocular representation of the visual field. The development of this projection involves a series of complex processes, whereby retinal axons must choose whether to cross the midline in the optic chiasm (Godement, 1994) and select their appropriate position within central targets of the dorsal lateral geniculate nucleus (dLGN) and superior colliculus (SC) (Cheng et al., 1995; Drescher et al., 1995; Feldheim, 1998). The initial innervation of the dLGN and of the SC by retinal axons is exuberant and imprecise: ipsilateral and contralateral retinal axons are largely intermingled. The production of the adult pattern involves the retraction of retinal axons from inappropriate areas whereas elaborate terminal arbors are formed in the areas in which they will remain (So et al., 1978; Land and Lund, 1979; Godement et al., 1984; Sachs et al., 1986; So et al., 1990; Bhide and Frost, 1991).

\footnotetext{
Received Dec. 16, 1998; revised April 27, 1999; accepted June 4, 1999.

This work was supported by the Institut National de la Santé et de la Recherche Médicale, the Centre National de la Recherche Scientifique, the Curie Institute, and by the European Commission (BMH4 CT97-2412). We thank Edward De Maeyer and Constantino Sotelo for their support and advice, Denis Lecren for photographic assistance, Chantal Alvarez for technical help, and Diana Haranger for animal care. We are very grateful to Claudine Botteri, Pierre Godement and Christine Métin for critical reading of this manuscript and useful discussions.

Correspondence should be addressed to Dr. P. Gaspar at the above address. Copyright (C) 1999 Society for Neuroscience $0270-6474 / 99 / 197007-18 \$ 05.00 / 0$
}

The dLGN of ferrets and cats has been a favored model to study the mechanisms involved in the segregation of the crossed/ uncrossed retinal fibers (Shatz, 1990; Katz and Shatz, 1996) because in these species retinal afferents from each eye occupy distinctive terminal fields in separate layers. In rodents however, although the binocular visual field is more restricted, crossed and uncrossed retinal fibers have a characteristic distribution in the binocular fields of the dLGN and in the superficial layers of the SC (Reese and Cowey, 1983; see Fig. 9), making it an equally valuable model to study the mechanisms of retinal axonal segregation during development.

Competition between axons from both eyes and spontaneous patterns of neural activity generated in the retina are thought to be essential in the emergence of the adult pattern. Removal of one eye results in an expansion of the projection from the remaining eye (Insausti et al., 1984; Godement et al., 1987; Thompson et al., 1995), whereas blockade of neural activity in the eye prevents the segregation of crossed and uncrossed RGC projections to the SC (Fawcett et al., 1984; Thompson and Holt, 1989). Similarly, blockade of activity in the target blocks segregation of retinal projections to the dLGN (Shatz and Stryker, 1988). As regulators of neural activity, neurotransmitters could play an important role in this process. Inhibition of acetylcholine neurotransmission in the retina disrupts the eye-specific layer formation 
in the dLGN in ferrets (Penn et al., 1998), whereas applications of the NMDA receptor antagonist APV in the dLGN, blocks the formation of On and Off sublaminae (Hahm et al., 1991). There is also evidence that increasing brain levels of noradrenaline in rats (Land and Rose, 1985) or of serotonin in hamsters affects the segregation of retinofugal fibers (Rhoades et al., 1993; Mooney et al., 1998).

In the present study, we examined the pattern of RGC projections in a mouse knock-out for monoamine oxidase A (MAOA), an enzyme which degrades serotonin (5-HT) and noradrenaline (NA). MAOA knock-out mice (MAOA-KO) have increased levels of brain 5-HT and NA during the first 2 weeks after birth (Cases et al., 1995). The excessive amounts of 5-HT have been shown to disrupt the formation of barrels in the primary somatosensory cortex (Cases et al., 1996). We show here that in MAOA-KO mice, the contralateral and ipsilateral retinal inputs to the dLGN and the SC fail to segregate during postnatal life after an initially normal development and that a normal phenotype can be obtained by inhibiting 5-HT synthesis during the first two postnatal weeks. During this period, we show that retinal fibers are capable of taking up 5-HT. This uptake is related to the expression of the plasma membrane transporter for serotonin (SERT) in a selected population of retinal ganglion cells. We show that RGCs also transiently express the vesicular monoamine transporter VMAT2, and thus could allow 5-HT to be stored in retinal axons. Furthermore, we observe that all RGCs express the $5-\mathrm{HT}_{1 \mathrm{~B}}$ receptor during embryonic development and postnatally. These receptors have previously been localized in retinal terminal axons and shown to reduce glutamatergic neurotransmission in adult rodents (Huang et al., 1993; Mooney et al., 1994; Boulengez et al., 1996). We propose that differential expression of SERT in a subpopulation of RGCs could modulate the sensitivity of RGCs to 5-HT during development.

\section{MATERIALS AND METHODS}

Animals. Two strains of normal mice and two strains of MAOA-KO mice were used. $\mathrm{C} 3 \mathrm{H} / \mathrm{HeJ}$ and $\mathrm{C} 57 \mathrm{BL} / 6 \mathrm{~J}$ inbred mice as well as MAOA-KO mice having a $\mathrm{C} 3 \mathrm{H} / \mathrm{HeJ}$ or $\mathrm{C} 57 \mathrm{BL} / 6 \mathrm{~J}$ background were produced at the Curie Institute (Orsay, France). Wild-type mice were also purchased from a commercial source (Iffa Credo, Reims, France). MAOA-KO mice with a $\mathrm{C} 3 \mathrm{H} / \mathrm{HeJ}$ background were serendipitously obtained during attempts to create a transgenic mouse line constitutively expressing interferon- $\beta$ (Cases et al., 1995). These mice were backcrossed for ten generations to obtain MAOA-KO mice with a C57BL/6J background (our unpublished data). The MAOA null allele was detected by PCR amplification. In this study, only the progeny of normal or homozygous/ hemizygous breeders were considered; mice heterozygous for the MAOA mutation were not examined. Animals with a $\mathrm{C} 3 \mathrm{H} / \mathrm{HeJ}$ background were analyzed at the following ages: embryonic day 13 (E13), E15, E17, postnatal day 0 (P0), P3, P6, P7, P8, P9, P10, P12, P15, P30, 2 months, and 2 years. The day of plug was counted as E1 and the day of birth as P0. Animals with a C57BL/6J background were analyzed at P30.

Drug treatments. To reduce 5-HT levels in MAOA-KO mouse pups, daily injections of parachlorophenylalanine, an inhibitor of 5-HT synthesis, were administered subcutaneously $(300 \mathrm{mg} / \mathrm{kg})$ in the neck from P0 to P15.

Enucleation of mouse pups. Mouse pups were anesthetized on ice, and a small cut was made along the line of the future opening of the eyelid. The eyeball was removed from its socket, and the optic nerve was severed. Pups were killed a minimum of $2 \mathrm{~d}$ later to allow the severed axons time to degenerate.

Anterograde axonal tracing by intraocular horseradish peroxidase injections. Mice were anesthetized either with a solution of $4 \%$ chloral hydrate $(0.1 \mathrm{ml} / 10 \mathrm{gm}$ body weight) for adults, or with a combination of ether and hypothermia for P3 and P8 pups. A solution of 30\% horseradish peroxidase (HRP) (type VI; Sigma, St. Louis, MO) in physiological saline solution was injected into the vitreous chamber of the left eye using a Hamilton syringe inserted just behind the corneoscleral margin of the eye. Four microliters was injected into the left eye of adults and 1-2 $\mu \mathrm{l}$ for pups. Animals were killed $24 \mathrm{hr}$ later: they were anesthetized and perfused through the aorta with $\sim 20 \mathrm{ml}$ ( $5 \mathrm{ml}$ for pups) of saline followed by $100-200 \mathrm{ml}$ (50 $\mathrm{ml}$ for pups) of $1 \%$ paraformaldehyde and $1.25 \%$ glutaraldehyde in $0.12 \mathrm{M}$ phosphate buffer, $\mathrm{pH}$ 7.4. The brain was then dissected out of the animal and left in $10 \%$ sucrose overnight. The following morning each brain was sectioned on a freezing microtome into $40 \mu \mathrm{m}$ sections collected serially in ice-cold phosphate buffer and stored for 2-24 hr before rinsing the sections for $10 \mathrm{~min}$ in $0.12 \mathrm{M}$ acetate buffer, $\mathrm{pH} \mathrm{3.3,} \mathrm{at} 4^{\circ} \mathrm{C}$. They were then reacted for HRP using tetramethylbenzidine $(67 \mathrm{mg} / \mathrm{l})$ as the chromogen. The reaction was started by the addition of $0.006 \% \mathrm{H}_{2} \mathrm{O}_{2}$. A second addition of $\mathrm{H}_{2} \mathrm{O}_{2}$ was made after 20 min. Slices were rinsed in $0.12 \mathrm{M}$ acetate buffer, $\mathrm{pH} 3.3$, at $4^{\circ} \mathrm{C}$ to stop the reaction. The reaction product was stabilized by a 3 min immersion in methyl salicylate before dehydration and mounting.

Computer analysis of volume of ipsilateral retinal projections to the $d L G N$. The area covered by HRP-labeled fibers was measured in complete series of coronal sections from normal and MAOA-KO mice at P3, $\mathrm{P} 8$, and P30-P34. Images of serial sections, including the dLGN, were digitized and the area of the ipsilateral projection to the dLGN was measured using a specially devised package from Imstar (Paris, France). The limits of the ipsilateral projection were either traced with the mouse on the computer screen or by setting an optical density threshold, in order to include all HRP-labeled elements (in this case, artifactual labeling such as blood vessels or precipitate was removed with the mouse). This measure does not distinguish between terminal fibers and fibers of passage and does not include isolated dispersed fibers. The volume of the labeled region for each section was calculated by multiplying the measured surface area by the thickness of the section. The total volume was obtained by adding this value for all sections containing detectable ipsilateral projections (15-20).

In a smaller sample of cases, the size of the dLGN was estimated from the same serial sections. For this, we delimited the external contours of HRP labeling in the contralateral dLGN and measured the area included within these contours: this measure includes both the area of contralateral HRP labeling and any unlabeled territory in the center.

Statistical comparisons between groups were made using Student's unpaired $t$ test

Uptake of tritiated 5-HT. C3H mouse pups were killed on postnatal days $6,8,10$, and 30 . Some mice were enucleated $3 \mathrm{~d}$ beforehand. The brain was removed, and coronal slabs (4- to 5-mm-thick) including the tectum were excised and kept in preoxygenated ice-cold Krebs'-Ringer's bicarbonate buffer supplemented with $0.4 \%$ glucose for cutting into $70-\mu \mathrm{m}$ thick slices using a vibratome. Slices were preincubated for $10 \mathrm{~min}$ at $37^{\circ} \mathrm{C}$, in Krebs'-Ringer's bicarbonate buffer containing $0.2 \%$ ascorbic acid and $10^{-7} \mathrm{M}$ pargyline (Sigma) to inhibit monoamine oxidase, maintained under an atmosphere of $92 \% \mathrm{O}_{2}$ and $8 \% \mathrm{CO}_{2} .5$ - $\mathrm{HT}$ uptake was initiated by the addition of $50 \mu$ l of 5 -hydroxy $\left(\mathrm{G}^{-}{ }^{3} \mathrm{H}\right)$ tryptamine creatinine sulfate $\left({ }^{3 \mathrm{H}_{5}}-\mathrm{HT} ; 10-20 \mathrm{Ci} / \mathrm{mmol}\right.$; Amersham, Arlington Heights, IL ) per $5 \mathrm{ml}$ of buffer to give a final concentration of $7 \times 10^{-7} \mathrm{M}$. Noradrenaline $5 \times 10^{-6} \mathrm{M}(l$-arterenol bitartrate; Sigma $)$ was also added to inhibit 5-HT uptake by dopaminergic and noradrenergic terminals. Slices were incubated for $15 \mathrm{~min}$ and uptake was terminated by transferring the slices to $3.5 \%$ glutaraldehyde in Krebs'-Ringer's bicarbonate, $\mathrm{pH} 7.4$, for $20 \mathrm{~min}$.

Controls were performed by the addition of the specific 5-HT transporter blocker fluoxetine $10^{-6} \mathrm{M}$ ) (Eli Lilly) to the preincubation medium. This abolished all labeling in terminals.

Fixed slices were mounted on gelatin-coated slides, air-dried for $5 \mathrm{~min}$ at room temperature, and dehydrated with $\mathrm{P}_{2} \mathrm{O}_{5}$ overnight. Sections were cleared in xylene for $1 \mathrm{hr}$, emulsion-coated with NTB2 (Eastman Kodak, Rochester, NY), and exposed for 7-10 d before developing with D-19 (Eastman Kodak).

Immunocytochemistry of 5-HT and SERT. 5-HT distribution in mice was studied using a rat monoclonal anti-5-HTantibody (1:70) from SeraLab. The specificity of this antibody has previously been described (Cases et al., 1996). SERT distribution was detected using a rabbit polyclonal anti-SERT antibody produced in the laboratory of Randy Blakely (Qian et al., 1995; see also Lebrand et al., 1998a).

Mice were deeply anesthetized and perfused through the aorta with $0.1 \mathrm{~m}$ sodium PBS, $4 \%$ paraformaldehyde. Brains were post-fixed for 24 $\mathrm{hr}$, cryoprotected in $30 \%$ sucrose for $48 \mathrm{hr}$, frozen, and serially cut in coronal sections, $40-\mu \mathrm{m}$-thick. Sections were rinsed in PBS + (PBS with $0.2 \%$ gelatin and $0.25 \%$ Triton $\mathrm{X}-100$ ) for at least $30 \mathrm{~min}$, and incubated overnight at room temperature with the primary antibodies. After wash- 
ing in $\mathrm{PBS}+$, sections were incubated for $2 \mathrm{hr}$ with biotinylated anti-rat IgG (1:200; Amersham) for 5-HT, or biotinylated anti-rabbit IgG (1:200; Sigma) for SERT, rinsed, and incubated for $1.5 \mathrm{hr}$ with the streptavidinbiotin-peroxidase complex (1:400; Amersham). After washing in Tris buffer $(0.05 \mathrm{M}, \mathrm{pH} 7.8)$, peroxidase was revealed in $0.02 \% 3,3^{\prime}$ diaminobenzidine tetrahydrochloride (DAB; Sigma), $0.003 \% \mathrm{H}_{2} \mathrm{O}_{2}$, and $0.6 \%$ nickel ammonium sulfate. Sections were mounted on gelatin-coated slides, dehydrated, and covered in Eukitt.

In situ hybridization. After cold anesthesia, whole heads of E13, E15, and E17 embryos and of P0, P1, and P4 pups were directly frozen by immersion samples in isopentane cooled to $-40^{\circ} \mathrm{C}$. P6, P7, P8, P9, P10, and P15 pups and adult mice were anesthetized with chloral hydrate anesthesia and decapitated. The retinas were dissected out and frozen as above, after inclusion in Tissue-tek. We obtained $15-\mu \mathrm{m}$-thick cryostat sections and processed for in situ hybridization.

To prepare the SERT cRNA probes, a cDNA fragment corresponding to nucleotides 1510-2009 of the transcript (Blakely et al., 1991) was amplified by PCR and subcloned into the plasmid pBluescript SKII(Stratagene, La Jolla, CA). The plasmid was linearized with BamHI (Boehringer Mannheim, Indianapolis, IN) for antisense RNA synthesis by T7 polymerase (Pharmacia Biotech) and with EcoRI (Boehringer) for sense RNA synthesis by T3 polymerase (Boehringer). The VMAT2 cRNA probes were synthesized from a bovine VMAT2 cDNA insert (Krejci et al., 1993) cloned into pCDNA3 (Invitrogen, San Diego, CA). The plasmid was linearized with HindIII (Appligene, Heidelberg, Germany) for antisense RNA synthesis by SP6 polymerase (Boehringer) and with EcoRI for sense RNA synthesis by T7 polymerase. The $5-\mathrm{HT}_{1 \mathrm{~B}}$ receptor cDNA in pBluescript $\mathrm{SKII}^{+}$was a gift from E. Doucet (Voigt et al., 1991). This plasmid was linearized with EcoRI for antisense RNA synthesis by T3 polymerase and with XhoI (Pharmacia Biotech) for sense RNA synthesis by $\mathrm{T} 7$ polymerase. In vitro transcription was carried out using a kit from Promega (Madison, WI), and probes were labeled with ${ }^{35}$ S-UTP (>1000 Ci/mmol; Amersham) as in Lebrand et al. (1998a).

In situ hybridization with cRNA probes was performed on $15 \mu \mathrm{m}$ sections through the retina and brain of whole heads flash frozen in liquid nitrogen. Tissue sections were post-fixed for $15 \mathrm{~min}$ in $4 \%$ paraformaldehyde, washed in $1 \times$ PBS, acetylated, washed in $1 \times$ PBS, dehydrated, and air-dried. Sections were covered with hybridization buffer containing $5 \times 10^{4} \mathrm{cpm} / \mu \mathrm{l}$ of the ${ }^{35} \mathrm{~S}-\mathrm{SERT},{ }^{35} \mathrm{~S}-5-\mathrm{HT}_{1 \mathrm{~B}}$, or ${ }^{35} \mathrm{~S}-\mathrm{VMAT} 2$ probes (50 $\mu \mathrm{l} / \mathrm{slide}$ ), and incubated overnight in a humid chamber at $48^{\circ} \mathrm{C}$. Washes were then performed as previously described by Lebrand et al. (1998a)

Autoradiographs were obtained by apposing the sections to Hyperfilm $\beta$ max, (Amersham) for $4 \mathrm{~d}$. For microscopic analysis, the slides were dipped in photographic emulsion (NTB2; Eastman Kodak) and exposed for about $12 \mathrm{~d}$, depending on the strength of the signal seen on the autoradiograph. After development of the emulsion with D-19 (Eastman Kodak), the sections were counterstained with cresyl violet.

Retrograde labeling of RGCs with fluorogold. To identify RGC bodies projecting either ipsilaterally or contralaterally, injections of fluorogold were made into the dLGN on one side of the brain on P1 and P30. The injections were aimed to be large enough to involve the optic tract. P1 pups were anesthetized on ice, a small incision was made in the scalp, and a Hamilton syringe was used to pierce the skull and inject $0.1 \mu \mathrm{l}$ of $5 \%$ fluorogold in $\mathrm{H}_{2} \mathrm{O}$. Pups were killed $3 \mathrm{~d}$ later and perfused with $4 \%$ paraformaldehyde. Then the entire head was post-fixed for $48 \mathrm{hr}$ and transferred to sterile $10 \%$ sucrose solution overnight, before sectioning at $15 \mu \mathrm{m}$ on a cryostat. Those brains in which it was established that the initial injection of fluorogold had been in the correct location were kept and alternate sections through the retina were used for in situ hybridization.

One-month-old mice were anesthetized with $4 \%$ chloral hydrate (10 $\mathrm{ml} / \mathrm{kg}$ ) and placed in a stereotaxic frame; $0.2 \mu \mathrm{l}$ of $5 \%$ fluorogold was injected $2.5 \mathrm{~mm}$ posterior to the bregma, $2.2 \mathrm{~mm}$ lateral to the midline, and 2-3 mm deep to the surface. Animals were perfused $48 \mathrm{hr}$ later. The eyes were removed, and the retina was dissected away from the pigmented epithelium before being flattened. The entire retina was then photographed at low magnification to measure the area of the ipsilateral crescent (the area containing a high density of ipsilaterally projecting RGCs), and the density of labeled RGCs was measured from three micrographs at a high magnification $(500 \times)$. The number of RGCs in the ipsilateral crescent was calculated from these measurements. Labeled RGCs outside the crescent were counted individually using an ocular grid.

\section{RESULTS}

Altered retinofugal projections in adult MAOA-KO mice Intraocular injections of HRP were used to label retinofugal axons and terminals, and the pattern of labeling was compared in complete series of coronal sections through the thalamus and SC of normal and MAOA-KO mice with a $\mathrm{C} 3 \mathrm{H} / \mathrm{HeJ}$ background. Results in normal $\mathrm{C} 3 \mathrm{H} / \mathrm{HeJ}$ mice were comparable to those previously reported from other strains (Lavail et al., 1978; Godement et al., 1984).

\section{Dorsal lateral geniculate nucleus}

In adult $\mathrm{C} 3 \mathrm{H} / \mathrm{HeJ}$ mice, the projections from the two eyes appear to occupy separate territories in the dLGN. Crossed retinal fibers innervate a large part of the dLGN, but leave a "gap" in the dorsomedial area (Fig. $1 B$ ), whereas ipsilateral retinal terminals form a group of several clusters in this same dorsomedial area (Fig. 1A). The ipsilateral and contralateral projection fields seem to be complementary as in each of the 15-20 coronal sections (40- $\mu$ m-thick) containing ipsilateral retinogeniculate projections, the size and position of the ipsilateral projection correspond to the size and position of the gap seen in the contralateral projection. Although some contralateral axons traverse the gap, these axons are on their way to the SC and do not have terminals in the dLGN (Bhide and Frost, 1991). In MAOA-KO mice, the distribution of RGC terminals is strikingly different: the contralateral projection innervates the entire dLGN, including the territory normally reserved for the ipsilateral projections (Fig. 1D). No sections contain a visible gap. Ipsilaterally, retinofugal axons, although remaining loosely confined to the dorsomedial portion of the dLGN (the binocular field), spread into the territory that is normally occupied exclusively by contralateral projections (Fig. $1 C)$. However, the distribution of these terminals is less dense than in normal mice.

We estimated the volume occupied by the ipsilateral retinal projections to the dLGN in 1-month-old animals. The volume of the ipsilateral projection was significantly enlarged in MAOA-KO mice, compared to wild-type mice (Fig. 2). This was not related to changes in the total volume of the dLGN that was not significantly different $(p=0.57)$ in the mutants (mean \pm SEM $=0.100 \pm$ $0.007 \mathrm{~mm}^{3} ; n=3$ ) compared with normal mice (mean $\pm \mathrm{SEM}=$ $\left.0.106 \pm 0.007 \mathrm{~mm}^{3} ; n=4\right)$, indicating that 5 -HT has not significantly affected the size of the target structure. Thereby, the percentage of dLGN volume occupied by ipsilateral fibers is increased from $15 \%$ in normals to $23 \%$ in mutants.

\section{Superior colliculus}

In normal adult mice, crossed retinal projections to the SC spread throughout the stratum griseum superficiale (SGS) and stratum opticum (SO), whereas the uncrossed projection is mainly concentrated in the SO with a few scattered fibers in the deeper SGS. The distribution of the ipsilateral retinal fibers varies markedly along the rostrocaudal extent of the SC: rostrally, it forms a dense mediolateral line that becomes patchy more caudally and finally concentrates in a medial patch in the caudal two-thirds of the SC (Fig. 3). In MAOA-KO mice, no qualitative differences could be seen in the contralateral projection (data not shown), whereas the ipsilateral projection differed considerably from normal: it was more diff use within the SO and spread further into the lower SGS (Fig. 3). Caudally, it remained distributed across the entire mediolateral axis for $\sim 200 \mu \mathrm{m}$ more than in the wild-type before becoming confined to the medial area. No dense clusters of 

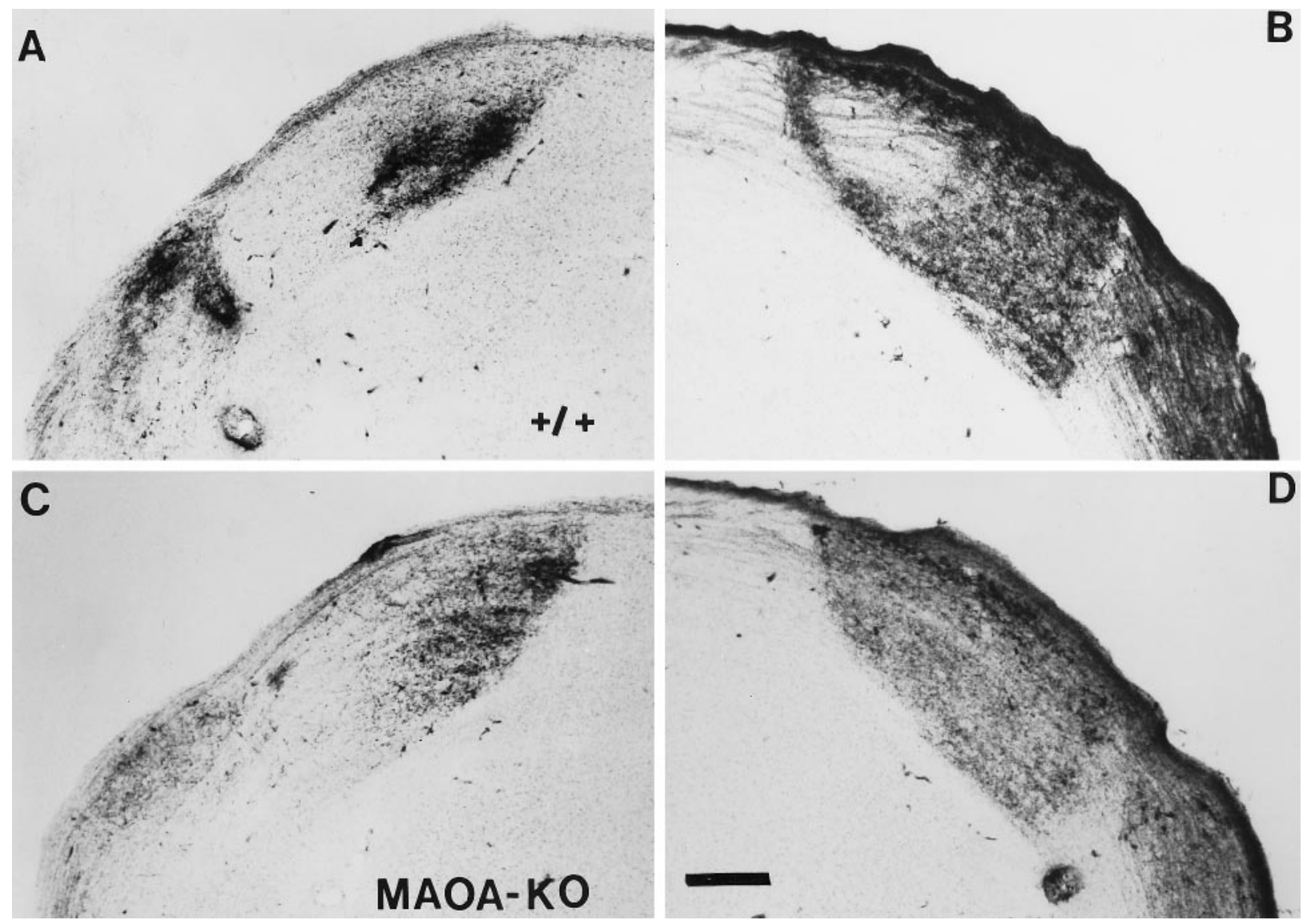

Figure 1. Intraocular injections of HRP in MAOA-KO mice reveal abnormal retinal projections to the dLGN. Sections in $A$ and $B$ are taken from the brain of a 1-month-old wild-type $\mathrm{C} 3 \mathrm{H} / \mathrm{HeJ}$ mouse and in $C$ and $D$ from a MAOA-KO mouse of the same age. $A$ and $C$ show the dLGN ipsilateral to the eye injected with HRP. $B$ and $D$ show the dLGN contralateral to the injected eye. $A, B$, In the wild-type adult, the ipsilateral projection forms dense patches close to the dorsomedial border of the $\mathrm{dLGN}(A)$. The contralateral projection fills most of the dLGN, but there is a clear gap that corresponds in size to the patch formed by the ipsilateral projection $(B) . C, D$, In MAOA-KO mice, the ipsilateral projection to the thalamus covers a larger area than in wild-type mice $(C)$; the contralateral projection occupies the entire dLGN and does not contain the characteristic gap $(D)$. Scale bar, $128 \mu \mathrm{m}$.

labeling typical of normal ipsilateral projections were present throughout the rostrocaudal extent of the SC (Fig. 3).

\section{Pretectal nuclei}

In the pretectal nuclei, retinal terminals formed clusters on both the ipsilateral and contralateral side. This arrangement was observed in normal as well as in MAOA-KO, but no detailed investigation of these nuclei was carried out to determine whether the size of the retinal projections was modified.

\section{Genetic background}

The inbred $\mathrm{C} 3 \mathrm{H} / \mathrm{HeJ}$ genetic background from which the MAOA-KO are derived carries the gene for retinal degeneration causing photoreceptors to start degenerating by P15 (Sidman and Green, 1965), although the number of RGCs is not affected (Williams et al., 1996). We examined the effect of MAOA deficiency in a genetic background with normal vision to ensure that the changes observed were not linked to retinal degeneration and to minimize the impact of any other unlinked modifier loci. Thus, HRP labeling of retinofugal axons was repeated in MAOA-KO mice with a $\mathrm{C} 57 \mathrm{BL} / 6 \mathrm{~J}$ genetic background. These mice also displayed a contralateral projection that filled the entire dLGN and displayed an extended ipsilateral projection to the dLGN as well as a diffuse ipsilateral projection to the SC. All the experi- ments that follow were carried out on animals with a $\mathrm{C} 3 \mathrm{H} / \mathrm{HeJ}$ background.

\section{Development of the retinal projections in MAOA-KO mice}

To identify when the abnormalities observed in MAOA-KO mice arise, we examined retinal afferents at P3 and at P8: before and after segregation has occurred in normal mice (Godement et al., 1984; Edwards et al., 1986) (Fig. 4).

In normal mice at $\mathrm{P} 3$, the contralateral projection to the thalamus is spread throughout the dLGN (Fig. 4B), and the ipsilateral projection, although much more sparse, covers a large part of the dorsomedial dLGN (Fig. 4A). In the SC, the ipsilateral projection spreads throughout much of the SO and SGS, occupying a much larger proportion of the SC than in the adult (data not shown). At this stage, the RGC projections in MAOA-KO are indistinguishable from those of normal mice in the dLGN (Fig. $4 C, D$ ) and the SC (data not shown). By P8, the adult pattern of ipsilaterally projecting and contralaterally projecting terminals becomes apparent in normal mice (Fig. 4E,F). However in MAOA-KO, the normal loss of terminals from selective regions has not occurred, and the fibers remain intermingled (Fig. $4 G, H)$. Quantitative evaluations in the dLGN showed that the ipsilateral projection is not significantly different in size in normal 


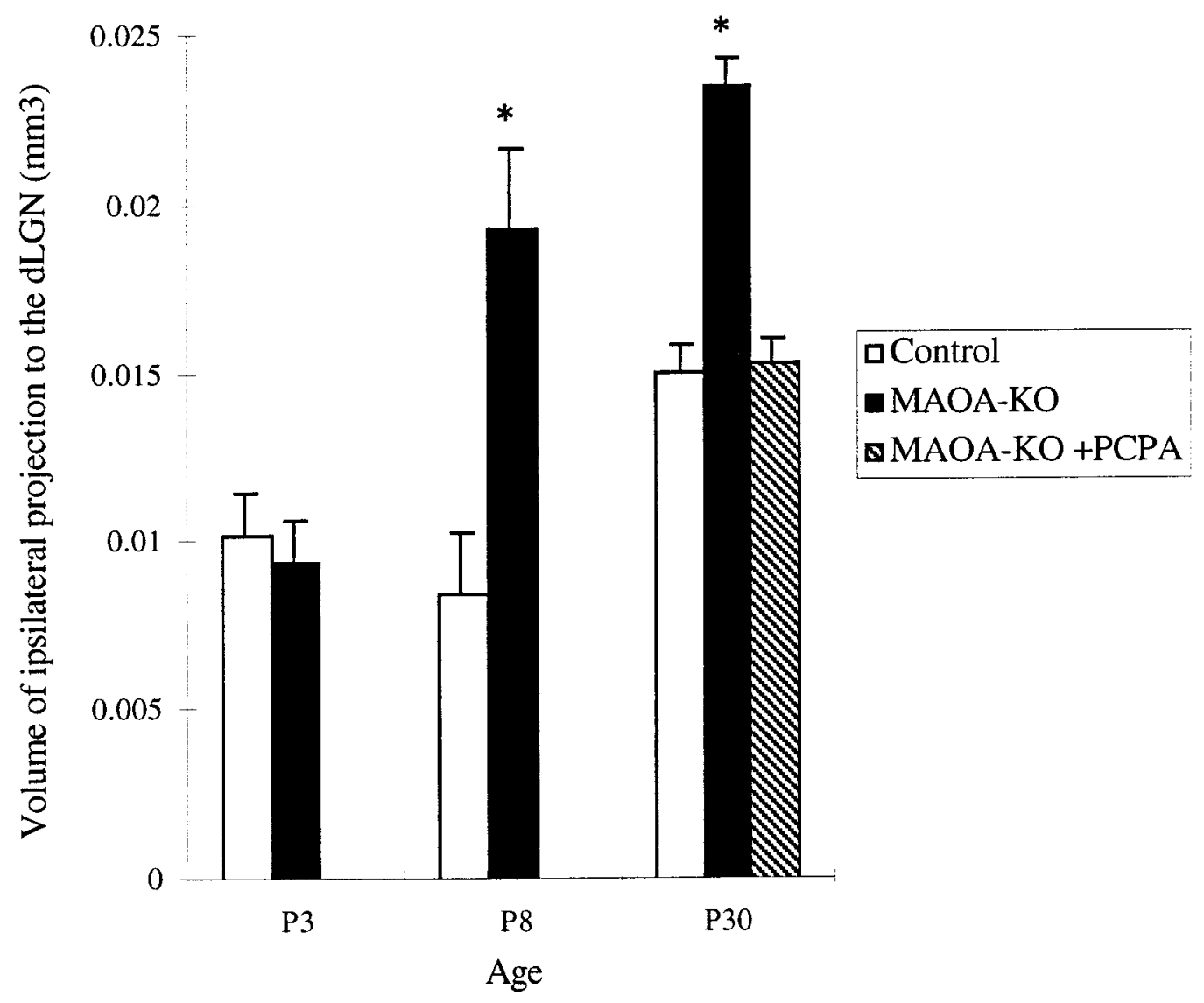

Figure 2. Quantification of the volume of the ipsilateral projection to the dLGN in wild-type and MAOA-KO mice. To estimate the volume of the dLGN receiving projections from the ipsilateral eye, the area of the dLGN covered by HRP reaction product in each section after intraocular injection of HRP, was measured using an image analysis program. The volume occupied by the terminals from the injected eye was calculated by multiplying the area measured by the thickness of each section $(40 \mu \mathrm{m})$ from serial coronal sections through the dLGN. Totals are shown in cubic millimeters for wild-type $\mathrm{C} 3 \mathrm{H} / \mathrm{HeJ}$ mice at P3 $(n=4$; mean $\pm \mathrm{SEM}=0.0102 \pm 0.0013), \mathrm{P} 8(n=3$; mean $\pm \mathrm{SEM}=0.0085 \pm 0.0018)$, and P30 $(n=7$; mean $\pm \mathrm{SEM}=0.0151 \pm$ $0.0007)$ (white bars); for MAOA-KO mice at P3 $(n=4$; mean $\pm \mathrm{SEM}=0.0094 \pm 0.0013), \mathrm{P} 8(n=4 ;$ mean $\pm \mathrm{SEM}=0.0192 \pm 0.0024)$, and P30 $(n=$ 4 ; mean \pm SEM $=0.0235 \pm 0.0009)$ (black bars); and for adult MAOA-KO mice treated with PCPA during the first 15 postnatal days $(n=2 ;$ mean \pm SEM $=0.01527 \pm 0.0008$ ) (striped bar). Values for MAOA-KO mice that differ significantly from wild-type are indicated by an asterisk above the bar ( $p \leq 0.01$, using Student's unpaired $t$ test). At P3, the ipsilateral projections of wild-type and MAOA-KO mice occupy the same volume of the dLGN, whereas at P8 and P30, the ipsilateral projection in MAOA-KO mice is significantly larger than in wild-type animals. The ipsilateral projections of MAOA-KO mice treated with PCPA occupy the same volume as those of wild-type mice. Error bars indicate the SEM for each value.

and MAOA-KO mice at P3 (Fig. 2), whereas at P8 the volume of the ipsilateral projection is significantly larger in MAOA-KO (225\% of controls) (Fig. 2). This increase thus appears to be more substantial than that measured at P30 (155\% of controls), suggesting that between $\mathrm{P} 8$ and 1 month some axonal remodeling may occur in the MAOA-KO.

Thus the development of the RGC projection pattern appears to be normal until P3, suggesting that the alterations are not related to abnormalities in the decussation of RGCs in the optic chiasm or to an abnormal target selection but to reduced segregation of contralateral and ipsilateral fibers into eye-specific regions between P3 and P8.

\section{Number and distribution of ipsilaterally projecting RGCs}

To determine whether this failure to segregate is the result of a decrease in naturally occurring cell death or an increase in aberrantly projecting RGCs, injections of the fluorescent tracer fluorogold were made in the dLGN of 1-month-old mice. The distribution of retrogradely labeled neurons was examined on flattened preparations of the retina. In normal mice, in agreement with previous descriptions, contralaterally projecting RGCs were found across the entire retina, whereas ipsilaterally projecting RGCs were found almost exclusively within a ventrotemporal crescent occupying $\sim 20 \%$ of the retinal surface (Dräger and Olsen, 1980). We found an identical pattern of distribution of labeled neurons in MAOA-KO. Numerical estimates of ipsilaterally projecting RGCs showed no significant difference between wild-type mice and MAOA-KO mice (Table 1). There was also no significant difference in the number of ipsilaterally projecting RGCs found outside the ventrotemporal crescent (Table 1). Thus, the observed defects in the MAOA-KO in the ipsilateral projections are unlikely to be caused by reduced cell death or to a substantial increase in ectopically placed RGCs.

\section{Role of excess serotonin in the developmental abnormalities}

MAOA deficiency causes increases of both 5-HT and NA levels in the brain that are most marked during development (Cases et al., 1995). In the barrelfield, we have been able to show that an excess of 5-HT during a short developmental time window was sufficient to cause permanent developmental alterations (Cases et 


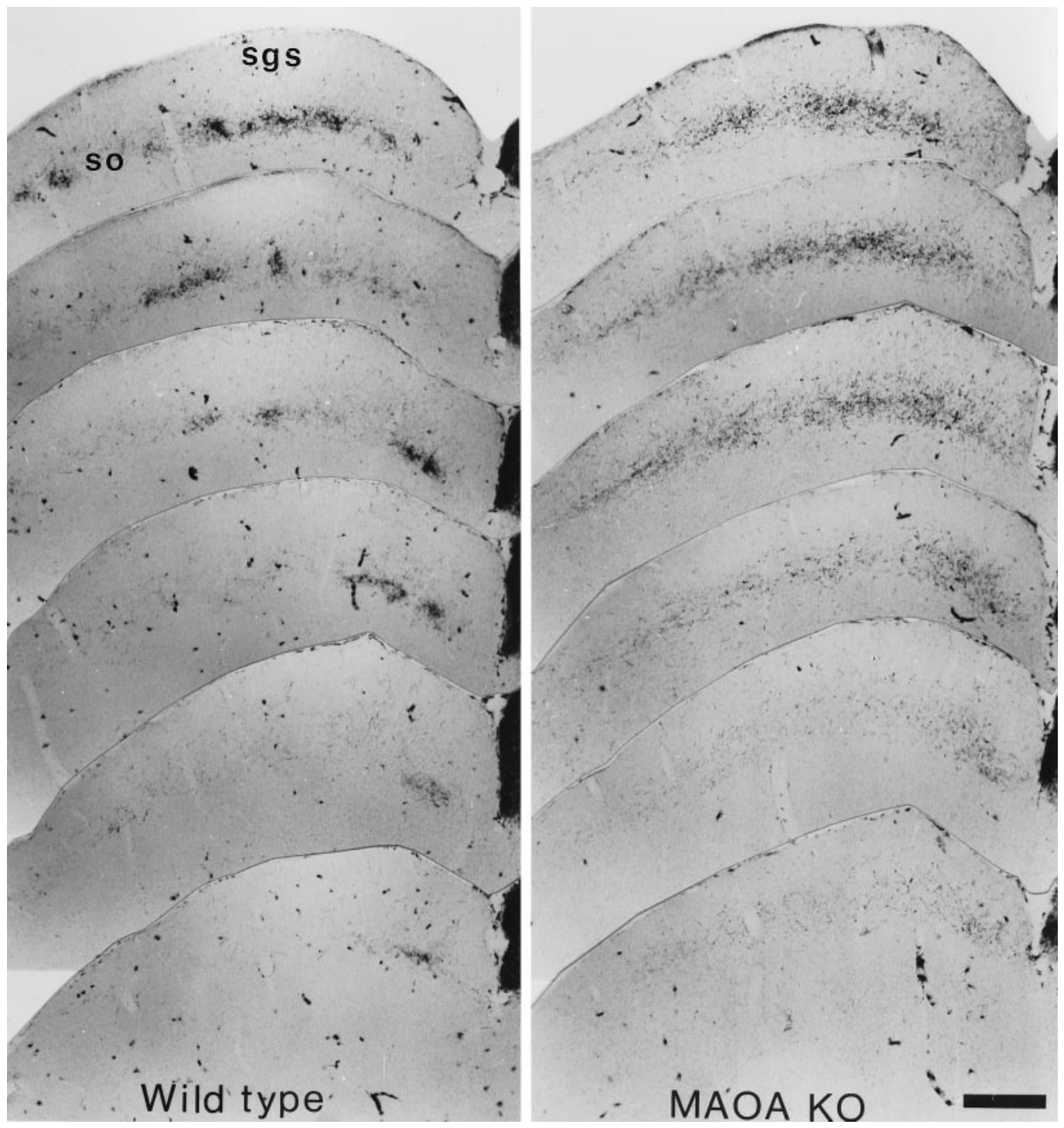

Figure 3. Abnormal retinal projections to the superior colliculus in MAOA-KO mice. One-month-old $\mathrm{C} 3 \mathrm{H} / \mathrm{HeJ}$ and $\mathrm{MAOA}-\mathrm{KO}$ mice received intraocular HRP injections and were sacrificed $24 \mathrm{hr}$ later. Rostrocaudal series of one in four, $40 \mu \mathrm{m}$ coronal sections through the SC are illustrated. In the SC of wild-type animals, the ipsilateral projection forms discernible patches in the stratum opticum (so) and lower stratum griseum superficiale ( $s g s$ ), and tends to cluster in a medial patch caudally; only scattered axons are visible in the upper SGS. In the SC of MAOA-KO mice, the ipsilateral projection appears to be more diffuse: it does not form patches in the SO, and it has a wider extension dorsally in the SGS, and caudally where it continues to be distributed mediolaterally even at caudal SC levels. Scale bar, $418 \mu \mathrm{m}$.

al., 1996; Vitalis et al., 1998). To determine whether the alteration in retinal projections is also caused by an increase in 5-HT levels, we administered parachlorophenylalanine (PCPA) $(300 \mathrm{mg} / \mathrm{kg}$ per $24 \mathrm{hr}$ ), an inhibitor of 5-HT synthesis (Koe and Weissman, 1966), during the first 2 weeks of postnatal life. In PCPA-treated MAOA-KO mice $(n=4)$, anterograde tracing of retinofugal axons with HRP showed an apparently complete segregation of the ipsilateral and contralateral retinal projections in the dLGN and SC. In particular in the dLGN, a clear gap is visible in the contralateral projection and quantitative evaluation of the volume of ipsilateral projections to the dLGN in two cases shows a reduction of this volume to normal values (Fig. 2). The percentage of dLGN volume occupied by ipsilateral fibers in MAOA-KO mice treated with PCPA (total volume of the $\mathrm{dLGN}=0.087 \pm$ $0.001 \mathrm{~mm}^{3}$; mean \pm SEM of $n=2$ ) was of $17.5 \%$ compared to $23 \%$ in untreated MAOA-KO mice and to $15 \%$ in normals. Although we cannot make statistical comparisons, because of the small number of cases that were fully quantifiable, PCPA treatment has certainly produced a reversion to the wild-type pattern. Thus, excess 5-HT is probably responsible for the alterations observed in MAOA-KO mice and the critical period for the developmental effects of 5-HT lies within the first two postnatal weeks.

\section{Serotonin immunolabeling in RGCs and in retinal projections}

When we looked for 5-HT in the brains of MAOA-KO mice (from E13 to P30), we found that 5-HT immunoreactivity could be detected all along the optic pathway from the RGC layer to axon terminals in the dLGN and the SC, between E15 and P15 (see also Cases et al., 1998). In the retina, 5-HT-immunolabeled neurons were found throughout the peripheral margin of the retina except at the dorsal pole (Fig. $5 A-C$ ). As illustrated in Figure $5 B, 5$-HT-labeled fibers could be followed running tangen- 

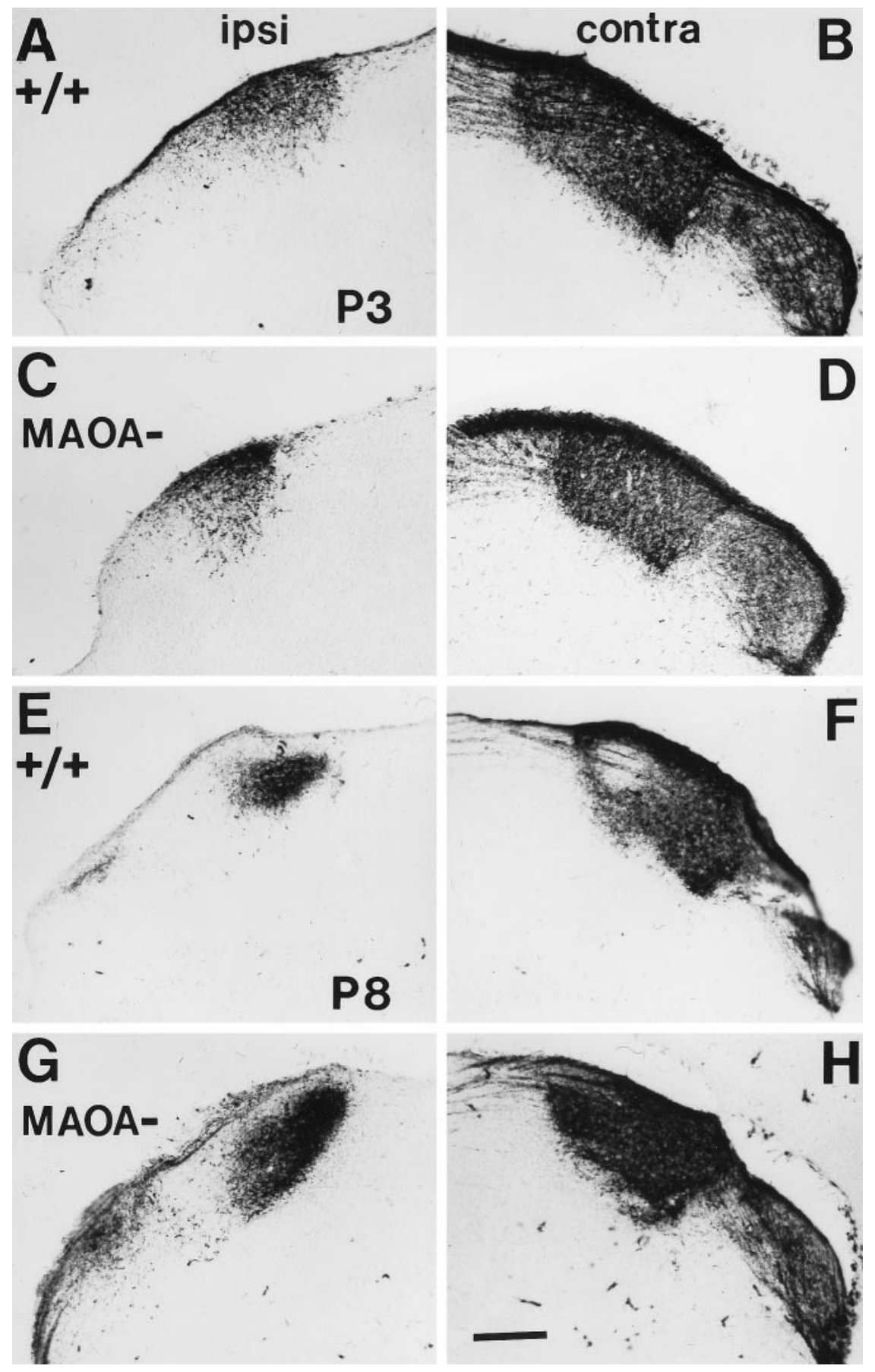

Figure 4. Development of retinal projections to the dLGN in wild-type and MAOA-KO mice. Intraocular injections of $\mathrm{HRP}$ into wild-type $\mathrm{C} 3 \mathrm{H} / \mathrm{HeJ}(+/+)$ animals aged $\mathrm{P} 3(A, B)$ and $\mathrm{P} 8(E, F)$ and MAOA-KO animals aged $\mathrm{P} 3(C, D)$ and $\mathrm{P} 8(G, H) . A, C, E$, and $G$ show the dLGN ipsilateral to the eye injected with HRP. $B, D, F$, and $H$ show the dLGN contralateral to the eye injected with HRP. $A, B$, In wild-type mice at $\mathrm{P} 3$, retinal projections fill a large proportion of the ipsilateral dLGN $(A)$ and the entire contralateral dLGN $(B) . C, D$, Ipsilateral and contralateral retinal projections illustrated here in MAOA-KO mice at $\mathrm{P} 3$ are identical to those of wild-type mice. $E, F$, In wild-type mice at $\mathrm{P} 8$, ipsilateral projections are confined to the dorsomedial part of the dLGN $(E)$, and the contralateral projection has withdrawn from this region $(F)$ : segregation of the two inputs appears complete in normal animals. $G, H$, In MAOA-KO mice at P8, fibers to the ipsilateral $(G)$ and contralateral $(H)$ thalamus still innervate overlapping territories: segregation has failed to occur. Scale bar, $110 \mu \mathrm{m}$.

\begin{tabular}{|c|c|c|c|}
\hline Genotype & $\begin{array}{l}\text { Size of the ipsilateral } \\
\text { crescent ( } \% \text { of retinal surface) }\end{array}$ & $\begin{array}{l}\text { Ipsilaterally projecting } \\
\text { RGCs in the crescent }\end{array}$ & $\begin{array}{l}\text { Ipsilaterally projecting } \\
\text { RGCs outside the crescent }\end{array}$ \\
\hline MAOA-KO $(n=7)$ & $21 \pm 1 \%$ & $2600 \pm 200$ & $21 \pm 4$ \\
\hline Wild-Type $(n=6)$ & $23 \pm 1 \%$ & $2700 \pm 300$ & $8 \pm 1$ \\
\hline
\end{tabular}

Values indicate mean \pm S.E.M.

tially in the ventral part of the retina. 5-HT labeling was also found in the optic nerve (Fig. $5 A, B$ ), in the chiasm (data not shown), and in the optic tract (Fig. 5D). 5-HT-labeled fibers that seem to correspond to retinal axons could also be followed up to the thalamus and SC from the earliest age examined, E15, until P15 (illustrated at E17 in Fig. 5D,E and at P8 in Fig. $5 F$ ). In the dLGN, thalamic neurons also contain 5-HT immunoreactivity during development in MAOA-KO mice (Cases et al., 1998), 


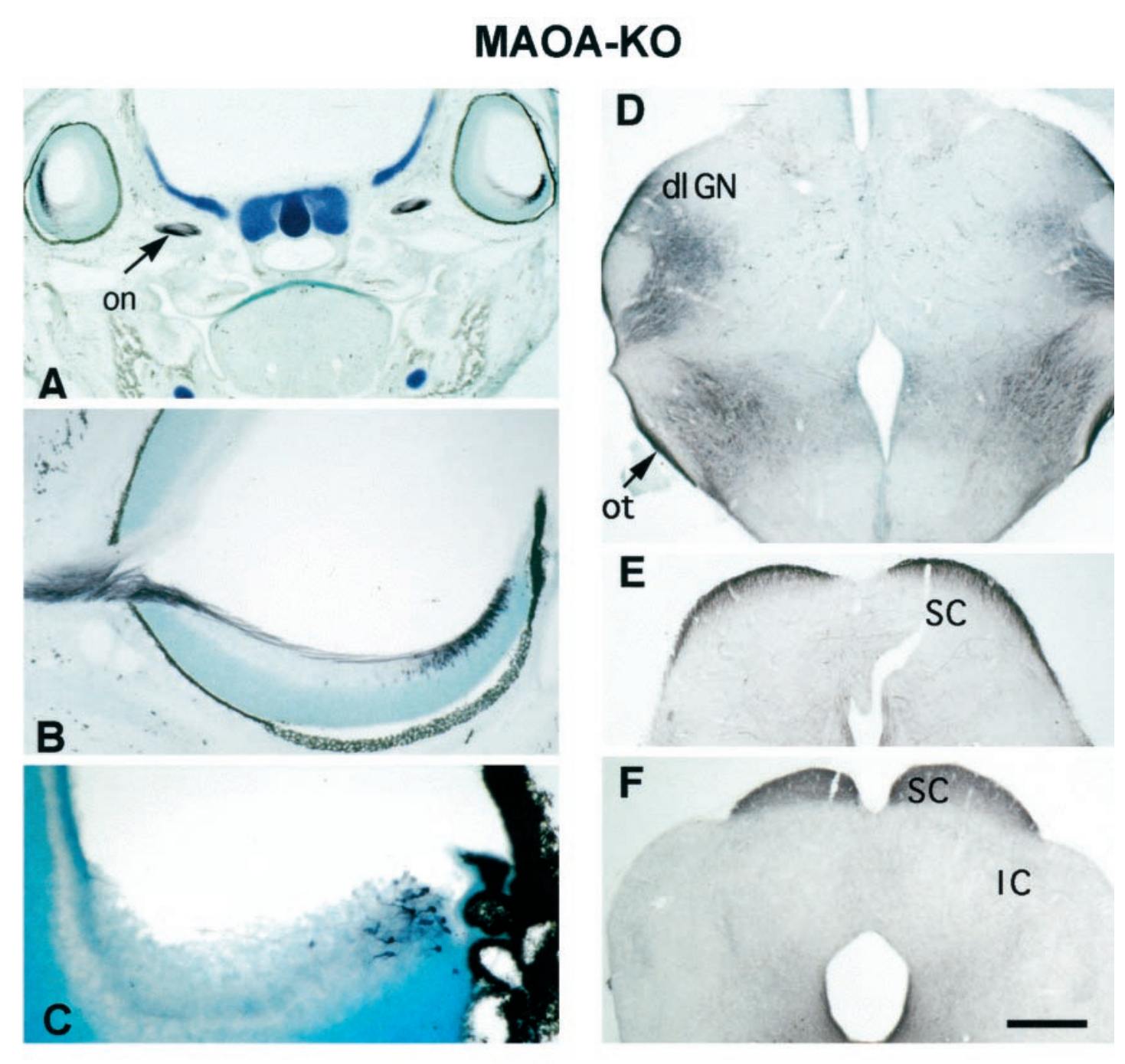

\section{Wild-type}
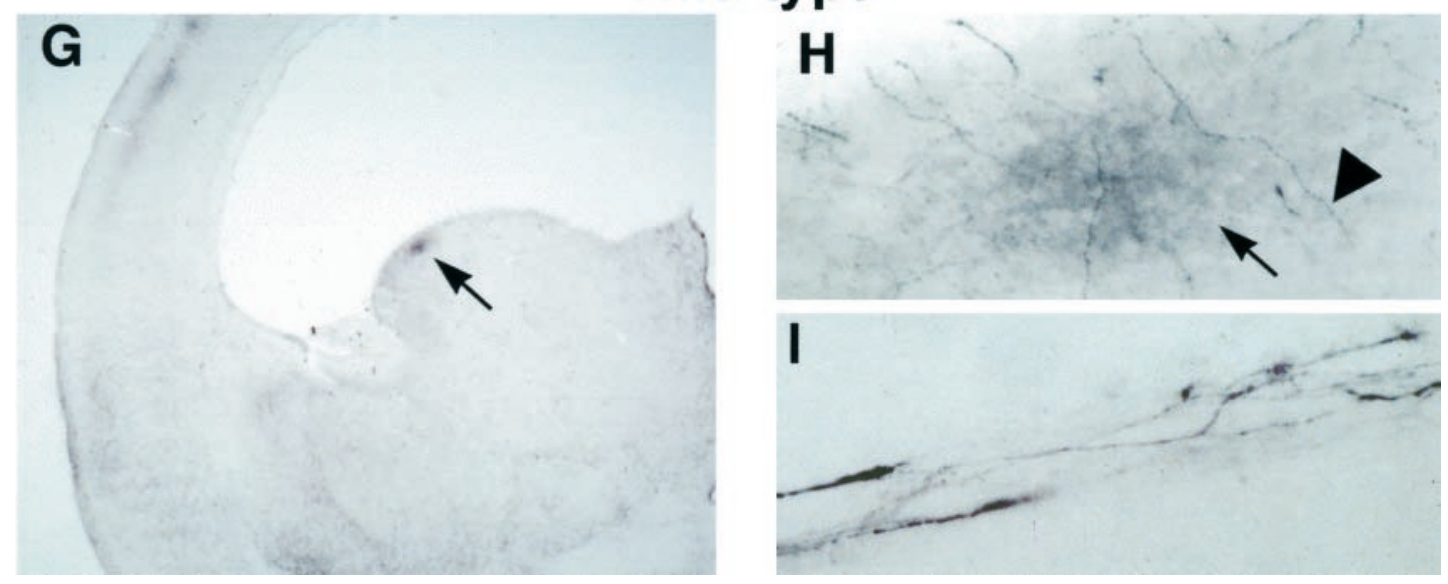

Figure 5. 5-HT immunolabeling in RGCs and their axons during development. 5-HT immunolabeling of the developing visual pathway is readily visible in MAOA-KO mice $(A-F)$, and faint 5-HT immunoreactivity is also detectable in retinal-like fibers in wild-type $\mathrm{C} 3 \mathrm{H} / \mathrm{HeJ}$ mice $(G-I)$. 5-HT immunolabeling (DAB-nickel staining) appears dark purple. Some sections were counterstained with methyl green (blue and green) to show the histological structures. $A-C$, In the retina, where the pigment epithelium appears black, 5-HT immunostaining is visible in the ganglion cell bodies in the peripheral ventral retina, shown here at E17 $(A, B)$ and $\mathrm{P} 3(C)$. Stained axons can be followed at the surface of the retinal ganglion cell layer $(B$, $C$ ) and in the optic nerve (on) $(A, B) . D, E$, As shown in an E17 embryo, intense 5-HT immunolabeling can be followed along the visual pathway: in the optic tract $(o t)$, in the superficial fibers coursing above the $\mathrm{dLGN}(D)$ and in the SC $(E)$. F, A similar pattern is visible in MAOA-KO mice postnatally, until P15, as illustrated here at P8. There is dense 5-HT immunostaining of the entire superficial layers of the SC that ends abruptly at the junction between the superior and inferior colliculi (IC), similarly to the retinal inputs. $G-I$, In wild-type mice, light 5 -HT immunolabeling could occasionally be detected in the visual pathway. $G$, A dense patch of 5-HT labeling (arrow) is visible in the dLGN of a P6 mouse. The localization (Figure legend continues) 
making it difficult to distinguish the 5-HT-labeled RGC terminals here. Dense clusters of 5-HT-immunoreactive fibers can also be seen in the pretectal nuclei from P3 to P15 (data not shown). In the SC, 5-HT labeling was present throughout the layers that receive input from the retina, i.e., the SGS and the SO (Fig. $5 F$ ). Treatment of MAOA-KO mice pups with fluoxetine, a specific inhibitor of the 5-HT plasma membrane transporter (SERT), abolishes the dense labeling of the SC leaving only the sparse varicose serotonergic innervation from the raphe (Cases et al., 1998), indicating that the dense labeling is caused by 5-HT uptake rather than 5-HT synthesis.

Occasionally, in wild-type $\mathrm{C} 3 \mathrm{H}$ mice, faint 5-HT immunoreactivity could be found in axonal terminal arbors that resemble those of RGCs. During embryonic life, 5-HT immunolabeling could be detected in growth cones and at the distal ends of axons in the optic tract (Fig. 5I). During postnatal life (from P0 to P9), 5-HT immunolabeling was visible in a few cases in terminal-like fibers forming a centromedial patch in the dLGN (Fig. 5G,H) and in the SO. On the other hand, no 5-HT-labeling was detectable in the retinas or the optic nerves of wild-type mice (during both embryonic and postnatal life) unless mice had been treated with the MAOA inhibitor clorgyline $(20 \mathrm{mg} / \mathrm{kg}$ per $12 \mathrm{hr}$ ) for $2 \mathrm{~d}$ beforehand (Vitalis et al., 1998). In previous immunocytochemical localizations of 5-HT during rat development, transient patterns of 5-HT innervation have been described in the dLGN and SC, that could also correspond in part to RGC fibers (Lidov and Molliver, 1982; Crissman et al., 1993; Dinopoulos et al., 1995), although they were not identified as such.

\section{High-affinity serotonin uptake and SERT immunolocalization in retinal projections}

To determine the pharmacological characteristics of the 5-HT uptake that was detected in the developing RGC, we examined uptake of tritiated 5-HT in fresh brain slices of the SC in normal mice, at P5, P8, and P10. This technique detects only high-affinity 5-HT uptake sites (using $7 \times 10^{-7}$ M 5-HT, in the presence of an excess of cold noradrenaline), and labeling is abolished in the presence of $10^{-6} \mathrm{M}$ fluoxetine. Autoradiographic analysis of the SC slices showed that in $\mathrm{P} 5-\mathrm{P} 10 \mathrm{C} 3 \mathrm{H} / \mathrm{HeJ}$ mouse pups, there was, in addition to the loose network of labeled fibers from the raphe, a dense labeling in the pretectal nuclei and in the SO and the upper part of the SGS (Fig. $6 A-C$ ). This labeling is not found in adult mice. Comparison of this transient labeling pattern with the pattern of retinal projections as labeled by intraocular HRP

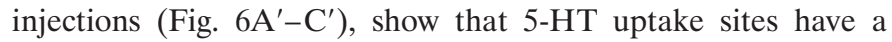
distribution that resembles the ipsilateral SC projection, but with additional sites in the superficial SGS. Binocular enucleations at P8 completely abolished this transient labeling confirming the retinal origin of these afferents (Fig. 6D). After monocular enucleation, the superficial labeling in the SGS was lost contralaterally to the lesion, whereas labeling in the lower part of the SGS and the patches in the SO disappeared ipsilaterally to the lesion (Fig. 6E). These experiments suggest that 5-HT-labeled retinal fibers innervating the SO and lower SGS originate in the ipsilat- eral eye, whereas those in the superficial SGS originate in the contralateral eye.

To confirm and extend these observations, the localization of the SERT was analyzed using immunocytochemistry in normal and MAOA-KO mice from E13 to P30. The protein appeared to be present exclusively on retinal axons, and no immunoreactivity was detected in cell bodies (not illustrated). In the retina, SERTimmunoreactive fibers were first detected at E15 running along the ventral surface of the retina (illustrated at E17 in Fig. $7 A$ ). In the optic nerve, they were mostly located ventrally (Fig. $7 A$ ) and laterally with a smaller medial contingent (Fig. $7 B$ ). In the optic chiasm, some SERT-labeled fibers could be seen to cross the midline (Fig. 7C). In the optic tract (Fig. $7 D, K$ ) and the central visual targets (Fig. $7 L$ ), SERT-positive fibers that appear to be RGC axons are intermingled with SERT-positive fibers that originate from the raphe. However, raphe fibers can be distinguished because they are characteristically very heavily stained with thick varicosities and tend to meander individually, whereas putative SERT-positive RGC axons are more lightly stained and tend to form bundles of smooth fibers (Fig. $7 K$ ) or clusters of very thin varicose fibers. Just postnatally, diffuse SERT labeling was observed in the dLGN, and fiber bundles were visible in the pretectum and the SC (Fig. 7L). Between P7 and P14, a dense patch of SERT labeling was noted in the dorsomedial dLGN in an area that corresponds to the ipsilateral projection field (Fig. 7E). This was confirmed by comparing consecutive sections from the same brain treated to reveal either HRP-labeled retinal afferents or SERT immunoreactivity (Fig. $7 F, G$ ). In the pretectal nuclei (data not shown) and in the SC, SERT-immunoreactive clusters were also visible from P7 to P14 (Fig. 7J, P9). Within the SC however, patches were not visible in all cases, possibly because of a technical limitation in detecting a lower density of immunoreactivity in this area. SERT labeling in the SC never produced the clear pattern observed after labeled 5-HT uptake of a band in the superficial SGS and distinct patches in the SO.

To confirm that the SERT-labeled fiber terminals seen in the dLGN and pretectal nuclei come from the retina and to establish whether they originate in the ipsilateral or contralateral retina, normal pups were unilaterally enucleated on P7 or P8 (when the segregation of ipsilateral and contralateral projections is almost complete), and sacrificed 2 d later. After enucleation, the dense patches of SERT labeling in the dLGN and in the pretectal nuclei disappeared ipsilaterally to the enucleation (Fig. 7H,I), confirming their retinal origin, and suggesting that they arise essentially from the ipsilateral eye. Because of the variability of SERT labeling in the SC at these ages, we were not able to draw conclusions about the effects of monocular enucleation in the SC.

In MAOA-KO mice, the distribution of SERT immunoreactivity was identical to that in normal mice in the retina, optic nerve, and optic tract. But in MAOA-KO mice, SERT labeling of retinal fibers was more diffuse in the dLGN at P8 and was almost impossible to detect at any age in the SC (data not shown).

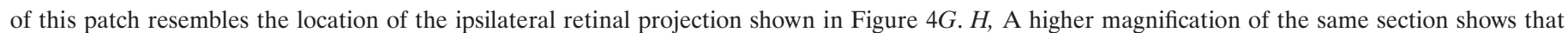

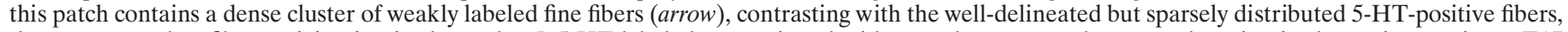

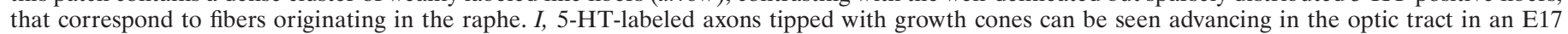
mouse. Scale bar (in $F$ ): $A, 750 \mu \mathrm{m} ; B, C, 190 \mu \mathrm{m} ; D, 300 \mu \mathrm{m} ; E, 260 \mu \mathrm{m} ; \mathrm{F}, 380 \mu \mathrm{m} ; G, 600 \mu \mathrm{m} ; H, 55 \mu \mathrm{m} ; I, 25 \mu \mathrm{m}$. 

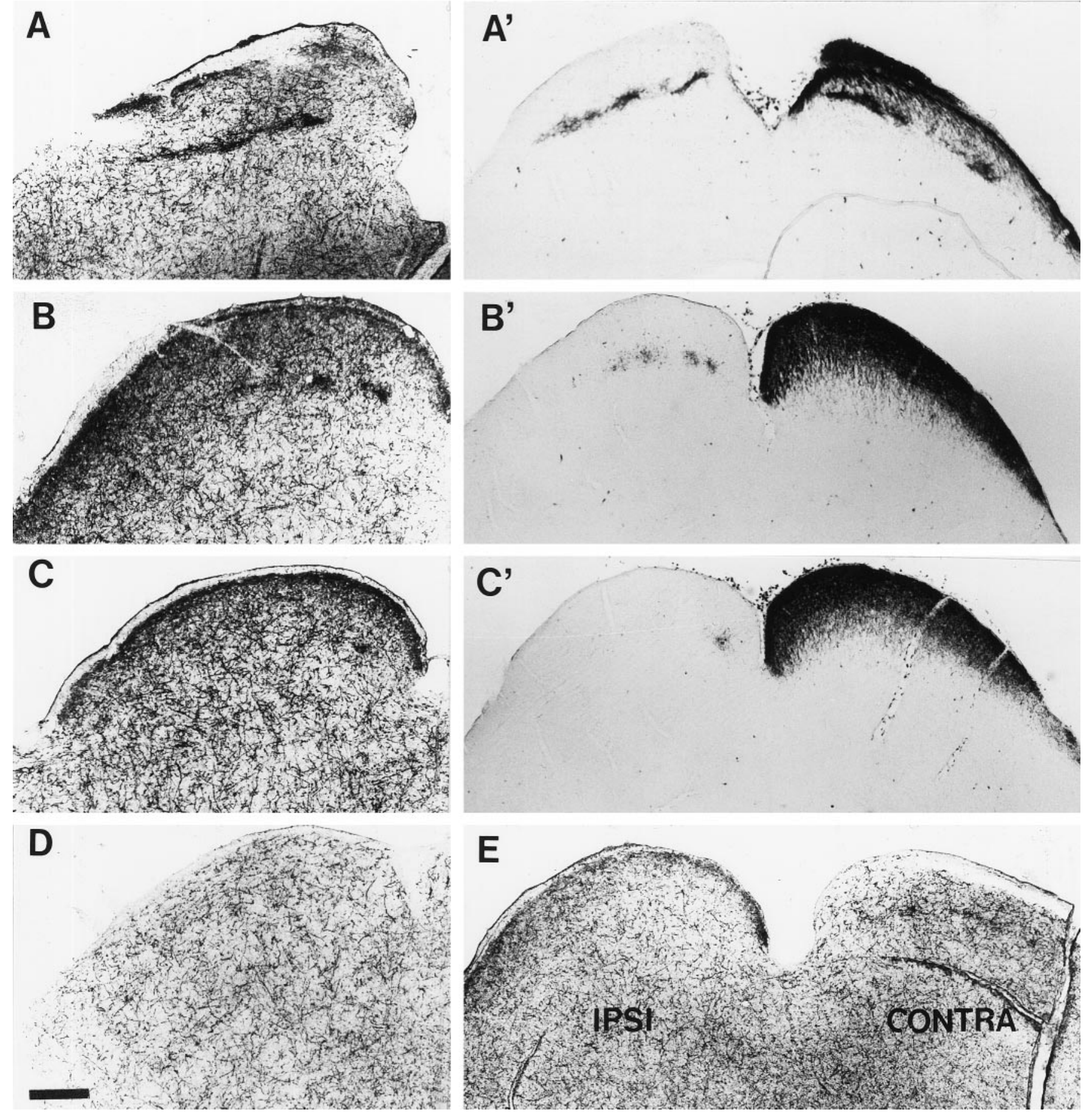

Figure 6. 5-HT* uptake in retinal fibers innervating the superior colliculus of wild-type mice. $A-E$, High-affinity uptake of tritiated 5-HT in 70- $\mu$ m-thick vibratome slices of $\mathrm{C} 3 \mathrm{H} / \mathrm{HeJ}$ mice aged P10. Labeling was revealed by autoradiography after emulsion coating. $A^{\prime}-C^{\prime}$, HRP labeling after injection into the left eye in a $\mathrm{C} 3 \mathrm{H} / \mathrm{HeJ}$ mouse aged $\mathrm{P} 8 . A-C$ illustrate three coronal sections from rostral $(A)$ to caudal $(C)$ through the superior colliculus. Only one colliculus is shown, and the midline is to the right. High-affinity 5-HT uptake is seen in two different locations: (1) in varicose fibers, distributed all over the brainstem, that correspond to fibers from the raphe; and (2) as dense accumulation of terminals in the superficial SGS in which they form a continuous band, and in the SO and lower SGS in which they form discrete patches caudally $(B, C)$ and a continuous line rostrally $(A)$. $A^{\prime}-C^{\prime}$, The distribution of retinal projections, labeled by intraocular injection of $\mathrm{HRP}$, at three equivalent coronal levels to those in $A-C$ is shown: ipsilateral projections can be observed in the left SC, and contralateral projections in the right SC. D, In a P10 mouse binocularly enucleated on P8, the areas of dense 5-HT uptake have completely disappeared in the SO and SGS of the SC (only one side is illustrated, the level corresponds approximately to that shown in $B$ ). E, In a P10 mouse in which the left eye was removed on P8, the area of dense 5-HT uptake is reduced contralaterally to the lesion in the SGS and ipsilaterally to the enucleation in the SO. Scale bar, $340 \mu \mathrm{m}$. 


\section{Expression of 5-HT1B receptors, SERT, and VMAT2 in the retina during development}

To further demonstrate that SERT is expressed in RGCs of thedeveloping retina, we performed in situ hybridization (ISH) using a probe for SERT. In parallel, we investigated the localization of the $5-\mathrm{HT}_{1 \mathrm{~B}}$ receptor $\left(5-\mathrm{HT}_{1 \mathrm{~B}}\right)$, and the VMAT2 genes, because we had previously found that they frequently coexist with transient SERT expression (Lebrand et al., 1998a,b). These expression patterns are described for normal $\mathrm{C} 3 \mathrm{H}$ mice, but were identical in MAOA-KO mice.

The first ganglion cells are born at E11, close to the optic nerve head, and their generation roughly follows a central to peripheral gradient (Dräger, 1985; Reese and Colello, 1992). Expression of SERT mRNA was first detected on E15 and continued until P9 [illustrated at E15 (Fig. 8B), P1 (Fig. 8F), and P6 (Fig. 8J)]. As seen from these coronal sections, SERT mRNA expression was always found in the peripheral and ventral retina. In order to define more accurately the region of the retina expressing SERT, projections on a tangential plane were reconstructed from serial coronal and horizontal sections through the eye of E17 embryos and P4 pups. At both ages, RGCs expressing SERT were found throughout the peripheral margin of the retina except at the dorsal pole (an E17 reconstruction is illustrated in Fig. 9C). Until $\mathrm{P} 4$, the hybridization signal appears to be fairly uniform throughout the labeled region, whereas from P6 onwards, SERT expression becomes confined to patches of a few cells located within this same retinal area (Fig. $8 \mathrm{~J}$ ).

The territory of SERT expression includes part of the domain of ipsilaterally projecting RGCs in the ventrotemporal crescent of the retina (Dräger and Olsen, 1980; Godement et al., 1987). To determine the degree of overlap between these two retinal domains, fluorogold was injected in the dLGN of normal mice at P1, which were then sacrificed at $\mathrm{P} 4$, and serial, coronal sections were processed for in situ hybridization to reveal the area of SERT expression (Fig. 9A) and photographed under UV illumination to reveal the location of retrogradely labeled neurons (Fig. 9B). We observed that in the ventrotemporal retina, the territory of SERT expression is located entirely within the domain of ipsilaterally projecting RGCs. However, the two regions do not coincide completely: more central regions of the ipsilateral crescent have no visible SERT expression; and SERT-expressing neurons in the nasal periphery of the retina fall outside the ipsilaterally projecting region.

$5-\mathrm{HT}_{1 \mathrm{~B}}$ transcripts were found in the ganglion cell layer of the retina from E15 until adult life [illustrated at E15 (Fig. 8C), P1 (Fig. 8G), and P6 (Fig. $8 K$ )]. In contrast with SERT expression, $5-\mathrm{HT}_{1 \mathrm{~B}}$ transcripts are distributed across the entire retina, and this expression continues in the adult (despite the degeneration of the photoreceptor cells of the retina which is characteristic of the $\mathrm{C} 3 \mathrm{H} / \mathrm{HeJ}$ mice).

VMAT2 mRNA is detectable in the ganglion cell layer throughout the retina at the earliest embryonic age examined (E13) but its expression is transient: the hybridization signal becomes weaker after birth and ends between P8 and P10 [illustrated at E15 (Fig. 8D), P1 (Fig. 8H), and P6 (Fig. 8L)].

Thus, each of these three genes, SERT, VMAT2, and 5-HT 1 B has a different spatial and temporal pattern of expression in the retina but they are all expressed by RGCs during a postnatal developmental period, which is critical for the segregation of retinal afferents, and during which 5 -HT can affect the final projection pattern.

\section{DISCUSSION}

In this paper we show that in MAOA-KO mice, elevated levels of brain 5-HT during the first 2 weeks of postnatal development prevent the ipsilateral and contralateral retinal projections from segregating into eye-specific areas in their target structures. Furthermore, we show that in normal and MAOA-KO mice SERT, VMAT2, and 5-HT $\mathrm{HB}_{1 \mathrm{~B}}$ are jointly expressed by a subpopulation of developing RGCs during the period of axonal remodeling. We propose that 5-HT could, via these molecules, influence retinofugal pathways and thereby help in sculpting their adult pattern of connections.

\section{Elevated serotonin levels prevent segregation of RGC projections}

In rodents, retinofugal axons invade their central primary targets, the dLGN and SC, during the second half of gestation. The majority of retinal fibers cross in the optic chiasm to reach contralateral targets, whereas a much smaller number of fibers remain uncrossed both in adults (Dräger and Olsen, 1980) and during the earliest stages of development (Jeffery, 1984; Colello and Guillery, 1990). Axons arriving from both eyes initially grow into overlapping areas in the dLGN and SC. The formation of the adult projection pattern, in which afferents from each eye occupy distinctive territories, occurs during the first two postnatal weeks (Godement et al., 1984; So et al., 1990). This development is characterized by an early period of exuberant axonal growth followed by a period of regressive events involving RGC death (Insausti et al., 1984; Jeffery, 1984) and axonal remodeling in target areas, which probably includes a combination of axonal retraction and selective axonal ingrowth (Edwards et al., 1986; Simon and O'Leary, 1992). In MAOA-KO mice, we found that segregation of retinal afferents does not occur by P8 and that this abnormality persists throughout adult life, but that a normal projection pattern can be reinstated by reducing 5-HT levels from P0 to P15. The distribution of ipsilaterally and contralaterally projecting axons in the optic nerve and optic tract does not appear to be disturbed in the MAOA - KO mice, as determined by the normal topography of SERT immunolabeling in these areas, and projections from both eyes appear to be normally distributed at P3. Furthermore, retrograde labeling of RGCs in adult mice (Table 1) demonstrates that the retinal origins and numbers of ipsilaterally projecting RGCs are identical in normal and in MAOA-KO mice; this suggests that the failure of segregation is neither caused by decreased amounts of RGC death, nor by pathfinding errors at the optic chiasm and leads us to propose that excess 5-HT has no effect on the early fate of retinofugal axons as they choose whether or not to cross in the optic chiasm or for selecting their primary targets in the thalamus and tectum during the second half of the gestation. Instead, excess 5-HT acts on the later postnatal events involved in the segregation of the ipsilateral and contralateral axons.

The effect we see of MAOA inactivation resembles that found by Land and Rose (1985) for elevated NA levels. They showed that NA injected subcutaneously during the first $4 \mathrm{~d}$ of postnatal life delayed the segregation of ipsilateral and contralateral fibers in the rat dLGN. In the MAOA-KO, brain NA levels are also increased because of a deficiency in the breakdown of this amine, although to a much lesser extent than 5-HT levels (Cases et al., 1995), thus it is possible that raised levels of NA contribute to the effect on retinal projection segregation. However, the apparent reversion of the phenotype after PCPA treatment, which inhibits tryptophan hydroxylase, the biosynthetic enzyme of 5-HT synthe- 


\section{E17}
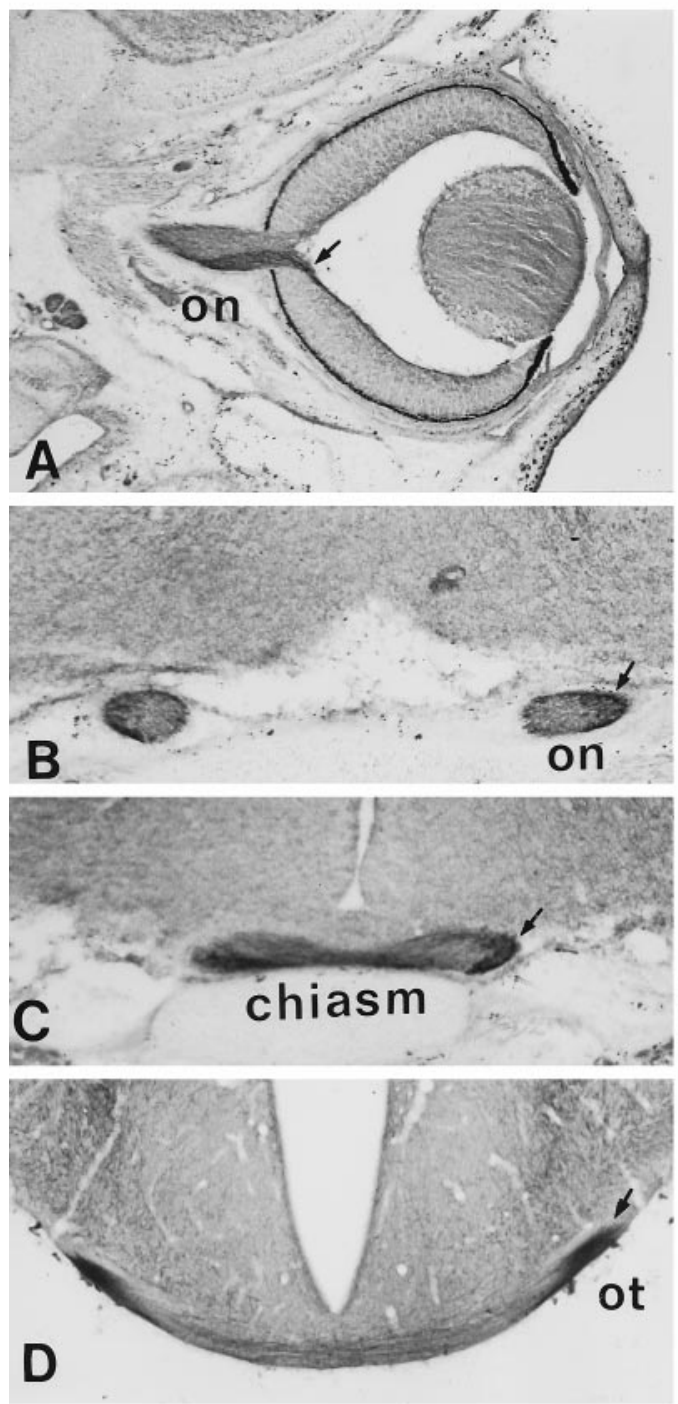

P 9

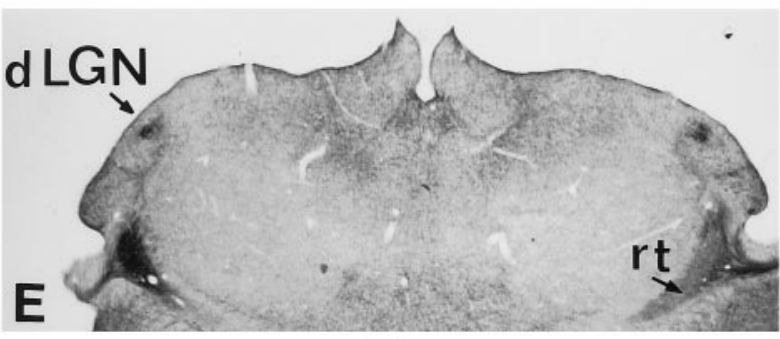

\section{SERT}

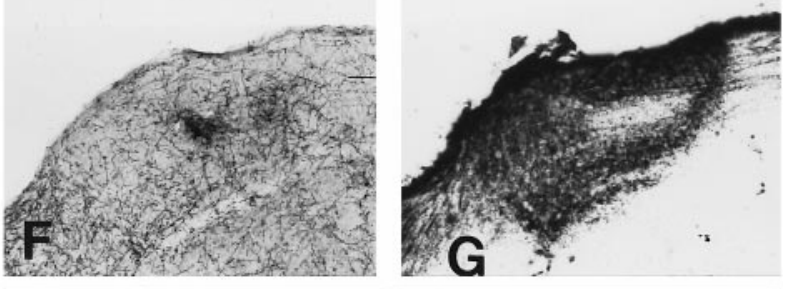

\section{enucleate contra}
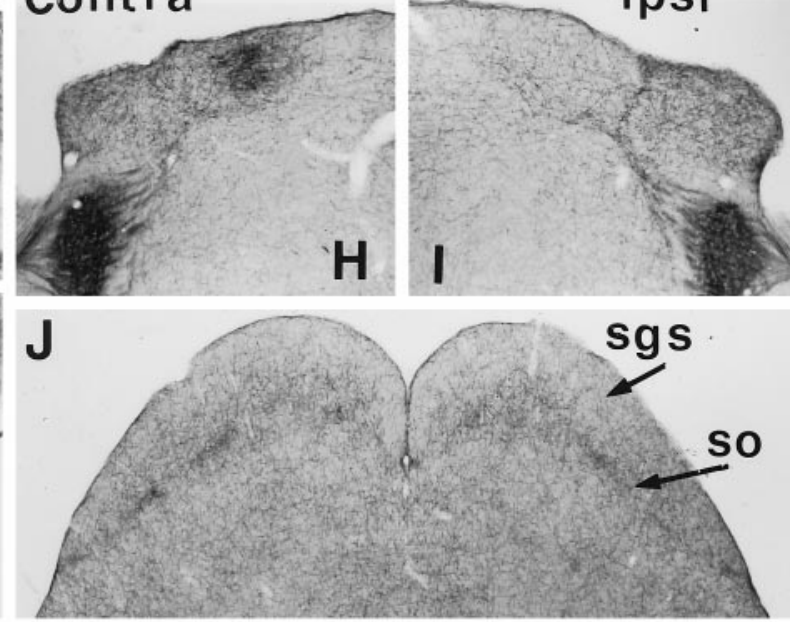

\section{Po}
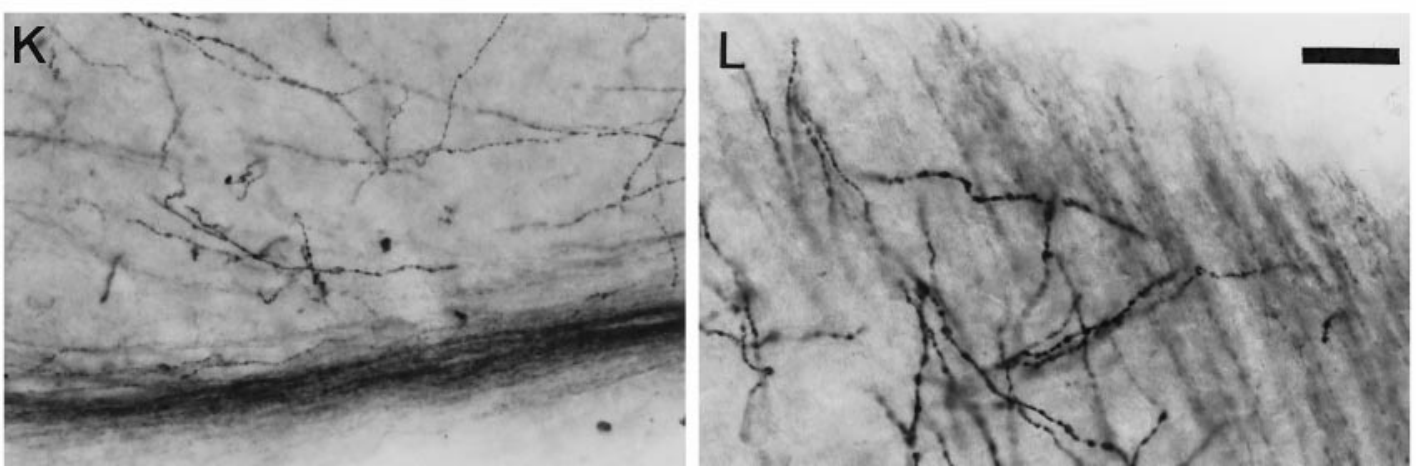

Figure 7. SERT immunolabeling on RGC axons during development in wild-type mice. SERT immunolabeling is visible on RGC axons but not cell bodies in the developing visual pathway. $A-D$, Coronal cryostat sections $(20 \mu \mathrm{m})$ from an E17 normal mouse. $A$, SERT-positive fibers are seen leaving the retina in the ventral part of the optic nerve. $B-D$, SERT immunolabeling can be followed in the optic nerve $(o n)(B)$, the chiasm $(C)$, and the optic tract $(o t)(D)$. Note that labeling is restricted to peripheral parts of the optic nerve. E-J, Free-floating sections from mice aged P8-P10. E, SERT immunolabeling is detected in a limited region of the dLGN (indicated by an arrow) as well as in thalamic axons in the reticularis (rt). $F$, $G$, After injections of HRP into one eye at P8, alternate brain sections were treated either to reveal the HRP $(G)$ or immunolabeled for SERT $(F)$. Exact superposition of adjacent sections was not possible because the two procedures resulted in different degrees of shrinkage of the tissue. However, alignment of consecutive sections indicated that the region of SERT immunolabeling in the dLGN corresponds to the area of the gap in contralateral projections $(G)$ that receives projections from the ipsilateral eye. $H, I$, After monocular enucleation at P8, SERT-labeled (Figure legend continues) 
sis, suggests that 5-HT has an essential role in this effect. Our observations and interpretation are also consistent with findings of Mooney et al. (1998) in hamsters who showed that 5-HT impregnated Elvax implanted in the tectum on the day of birth prevents the segregation of retinal axons. These authors had previously shown that a single injection of the 5-HT neurotoxin, 5,7-DHT on the day of birth caused a lack of segregation of retinal fibers (Rhoades et al., 1993), but the interpretation of this experiment is complicated by the fact that $5,7-\mathrm{DHT}$ is a substrate for SERT and could thus be taken up in the developing retinal fibers.

\section{Possible targets of excess 5-HT in the primary visual pathways}

The effects of 5-HT could be achieved by modifying the levels of neural activity in the developing retinof ugal axons. Many lines of evidence suggest that segregation of inputs from both eyes is an activity-dependent process (for review, see Shatz, 1990; Katz and Shatz, 1996). Segregation occurs before eye opening, but spontaneous activity has been demonstrated in the RGCs of prenatal rats (Galli and Maffei, 1988) and ferrets (Meister et al., 1991). Ex vivo preparations in neonatal mouse $(\mathrm{P} 0-\mathrm{P} 4)$ have confirmed that these action potentials reach the dLGN and are transmitted via excitatory neurotransmission (AMPA-receptor dependent) to the thalamic target cells (Mooney et al., 1996). Blocking neural activity in the target by infusion of tetrodotoxin (TTX) results in a lack of segregation of ipsilateral and contralateral fibers (Shatz and Stryker, 1988). In rats, bilateral TTX injections in the eye result in ipsilateral projections being more widespread (Fawcett et al., 1984). The distribution of retinal axon terminals that we observe in MAOA-KO mice is similar to that seen after TTX treatments. 5-HT could inhibit transmission of RGC activity to their targets by acting presynaptically on $5-\mathrm{HT}_{1 \mathrm{~B}}$ receptors expressed on retinal axons. We have demonstrated that RNA for this receptor is expressed in RGCs from late prenatal life onwards. Previous studies in adult rodents had inferred the presence of this receptor subtype on retinotectal projections by electron microscopic observations (Boulenguez et al., 1996). Stimulation of $5-\mathrm{HT}_{1 \mathrm{~B}}$ receptors has been shown to inhibit the activity of retinotectal axons (Mooney et al., 1994). It is therefore possible that an excess of brain 5-HT blocks the activity-dependent mechanisms that allow the fine-tuning of retinal projections.

5-HT could also affect postsynaptic target cells. Several 5-HT receptors are present in the $\mathrm{SC}\left(5-\mathrm{HT}_{2 \mathrm{~A}}, 5-\mathrm{HT}_{7}\right)$ and $\mathrm{dLGN}$ $\left(5-\mathrm{HT}_{2 \mathrm{C}}, 5-\mathrm{HT}_{7}\right)$ during development or in the adult (Pazos et al., 1985; Hellendal et al., 1993; Vizuete et al., 1997). In MAOA-KO mice, high levels of 5-HT could saturate these postsynaptic 5-HT receptors, causing a failure in the normal activity-dependent segregation mechanisms.

Another possible site of action of 5-HT is a direct trophic effect of 5-HT on RGCs. 5-HT has been reported to promote or inhibit axonal growth and increase cell survival in vitro (Goldberg et al., 1991; Dooley et al., 1997; Lotto et al., 1999) (for review, see Lauder, 1993). However, effects on cell death or neurite outgrowth are unlikely to explain the phenotype of MAOA-KO mice, because RGC cell death appears unchanged, and the exuberance of retinal axon outgrowth remains limited to the confines of their normal initial target territories, the ipsilateral projection filling only $23 \%$ of the dLGN in the adult. This is dissimilar to the trophic effects that are observed after monocular enucleation for instance, in which RGC cell death is reduced and not only are the normally transient exuberant RGC projections maintained, but additional branching occurs so that the ipsilateral projection of the spared eye occupies $\sim 70 \%$ of the dLGN in the adult. (Fawcett et al., 1984; Jeffery, 1984; Godement et al., 1987; So et al., 1990; Thompson et al., 1995).

\section{SERT in a subpopulation of RGCs}

Our observations clearly demonstrate that SERT is transiently expressed by RGCs during a limited period of development even though developing RGCs do not have the capacity to synthesize 5-HT, because all 5-HT immunolabeling disappears in retinal axons after fluoxetine treatment (Cases et al., 1998). SERT mRNA is visible in RGCs, and SERT protein is immunolocalized in retinal axons in the retinal cup, the optic nerve, and the optic tract. Furthermore, 5-HT is taken up by retinal terminal arbors with a high affinity, and this uptake is selectively inhibited by fluoxetine. This finding allows us to interpret previous autoradiographic observations showing transient citalopram binding in the optic nerve during embryonic mouse development (Brüning et al., 1997). We also observed the transient expression of the vesicular monoamine transporter VMAT2 in RGCs. The presence of both transporters in the same cell could allow internalized 5-HT to be concentrated in synaptic vesicles, although this still needs to be directly demonstrated.

Of particular interest is the restricted extent of SERT expression during this period in a small, but well-defined region of the retina. This could confer unique neurotransmission properties on a group of RGCs, that combined with positional identity cues provided by other genes (Cheng et al., 1995; Drescher et al., 1995), could help to specify the projection patterns of individual RGCs. How could this influence the segregation of retinal terminals? One possibility is that SERT expressed by RGC axons and terminals could capture 5-HT released by raphe fibers and thereby reduce locally its concentration at 5-HT1B receptors that are present on the same axons. Since the effect of 5-HT $\mathrm{HB}_{1 \mathrm{~B}}$ receptor activation is to reduce the activity of RGCs (Mooney et al., 1994), if we assume that these high-affinity receptors are activated by ambient levels of 5-HT (Bunin and Whightman, 1998), then the SERT-expressing RGC terminals would be relatively more active than the ones that do not express SERT in normal development. Another possibility is that 5-HT taken up by SERT from the extracellular space into RGC axonal terminals could be concentrated into secretory vesicles by VMAT2 and subsequently released as a "borrowed" neurotransmitter, as has been shown in other systems (Vanhatalo and Soinila, 1994). This would allow activity-dependent release of 5-HT by RGC axons producing localized bursts in 5-HT concentration well above background levels that could activate low-affinity receptors such as the postsynaptic $5-\mathrm{HT}_{2}$ and $5-\mathrm{HT}_{3}$ receptors (Hoyer et al., 1994) on

\section{$\leftarrow$}

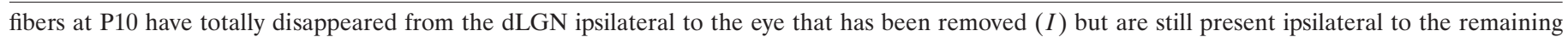

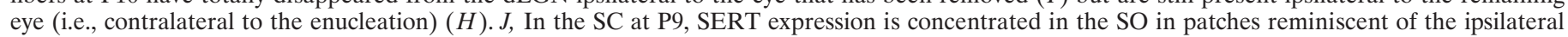

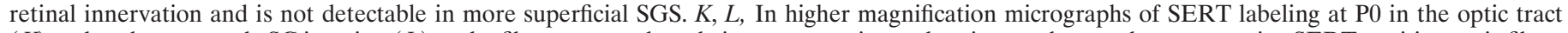

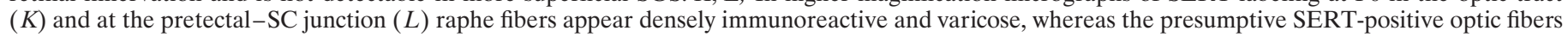

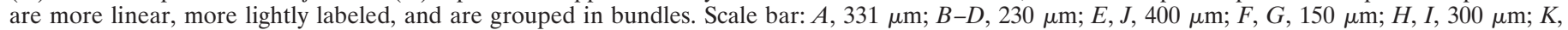
$L, 35 \mu \mathrm{m}$. 

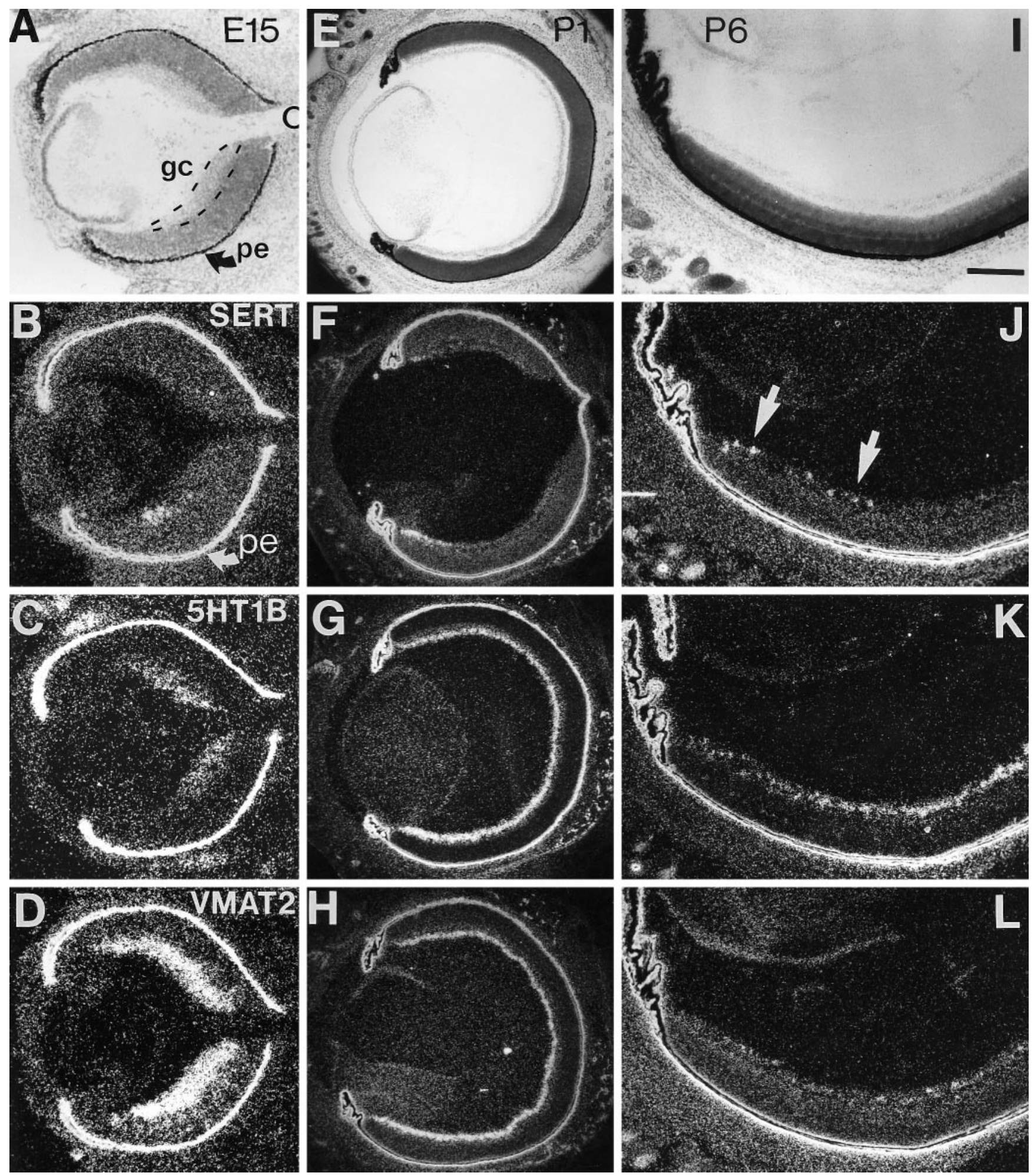

Figure 8. In situ hybridization of SERT, 5- $\mathrm{HT}_{1 \mathrm{~B}}$ receptor, and VMAT2. Antisense cRNA ${ }^{35}$ S-labeled probes to SERT $(B, F, J)$, the 5-HT ${ }_{1 \mathrm{~B}}$ receptor $(C, G, K)$ and VMAT2 $(D, H, L)$ were hybridized to $15-\mu$ m-thick coronal sections through the retina at E15 $(A-D)$, P1 $(E-H)$, and P6 $(I-L)$. The retinal pigmented epithelium ( $p e$ ) was nonspecifically labeled by sense and antisense probes. $A, E$, and $I$ are bright-field photomicrographs of Nissl-stained sections. $A$, At E15, two layers can be distinguished in the retina: the undifferentiated neuroepithelial cells and the postmitotic retinal ganglion cell layer $(g c)$. The latter, outlined by a dashed line, first appears close to the optic nerve head $(O)$ and subsequently at the periphery. $E$, At P1, the ganglion cell layer is clearly separated from the others by the inner plexiform layer. $I$, By P6, differentiation of the different retinal cell types is complete, and all layers of the retina are distinguishable. $B-D$, At E15, a small area at the periphery of the retinal ganglion cell (RGC) layer is positive for SERT ( $B$ ), and a hybridization signal is observed in the entire RGC layer with probes for 5-HT $1 \mathrm{~B}(C)$ and $\mathrm{VMAT}_{2}(D)$. $F-H$, At P1, a restricted territory at the periphery of the RGC layer expresses SERT $(F)$, whereas the entire RGC layer is still labeled with 5-HT 1 B $(G)$ and VMAT2 $(H)$. $J-L$, At P6, SERT mRNA labeling has become confined to small patches in the ventral part of the peripheral retina $(J)$. 5-HT $\mathrm{HB}_{1 \mathrm{~B}}$ expression still extends throughout the RGC layer $(K)$, whereasVMAT2 labeling $(L)$ starts to decrease compared with younger ages. Scale bar: $A-D, I-L, 150 \mu \mathrm{m} ; E-H, 300 \mu \mathrm{m}$. 

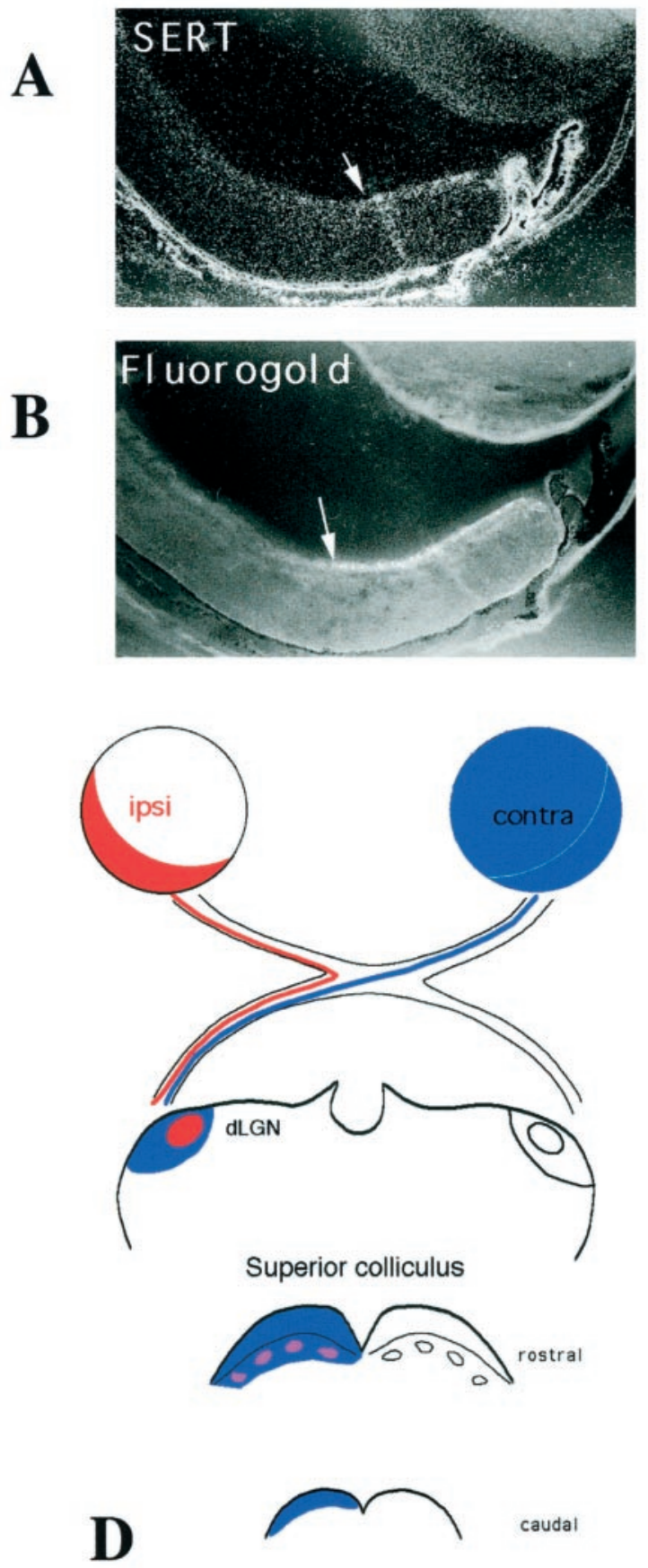

caudal
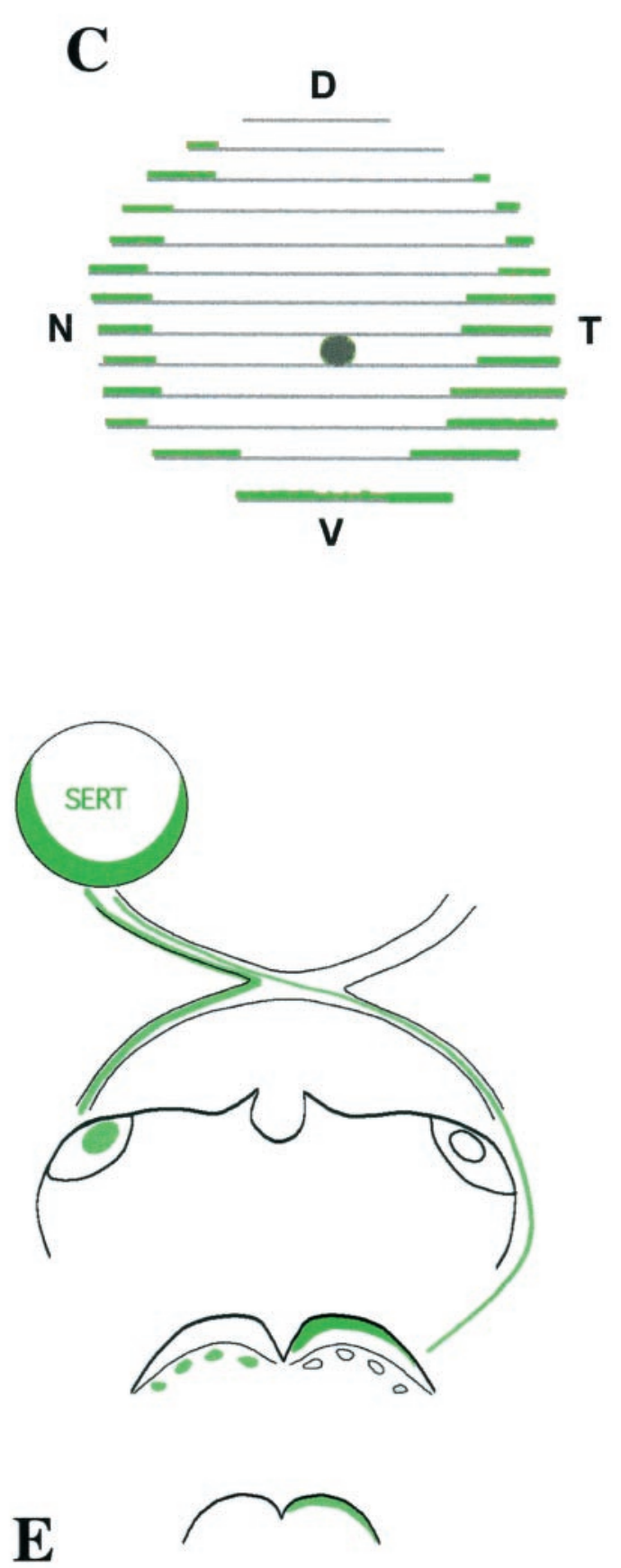

Figure 9. SERT expression in relationship to ipsilateral retinal projections. $A, B$, Coronal sections taken through the retina of a $\mathrm{P} 4$ mouse pup injected in the ipsilateral thalamus on P1 with fluorogold. $A$, ISH using a probe for SERT mRNA. An arrow indicates the furthest extent of the ISH signal in the RGC layer. B, Same section photographed under UV fluorescence to reveal fluorogold retrogradely transported to the retina (magnification, $44 \times$ ). The arrow indicates the edge of the ipsilaterally projecting region. Note that SERT hybridization signal in the ventral retina falls within the region containing ipsilaterally projecting cells. $C$, A reconstruction of the retina was made from a series of $15 \mu \mathrm{m}$ horizontal sections, $60 \mu \mathrm{m}$ apart, taken through one $\mathrm{E} 17 \mathrm{C} 3 \mathrm{H} / \mathrm{HeJ}$ retina and processed for ISH. The circumference of each retinal section is represented as a straight gray line with the region of SERT expression in RGCs represented by a thicker green bar. In sections through the lens, the end of the ganglion cell layer was taken as the end of the line. However, the most dorsal and the three most ventral sections that contained a continuous ganglion cell layer were divided at the point closest to the surface of the skin for the purpose of this reconstruction. The position of the optic nerve is indicated by a filled circle. The labeled territory forms a peripheral crescent that only excludes the dorsal peripheral retina. $D$, Summary of the anatomical organization of the crossed and uncrossed retinal pathways in rodents as previously described in the literature (Dräger and Olson, 1980; Métin et al., 1983; Reese and Cowey, 1983; Godement et al., 1984). The ipsilateral projections, shown in red, originate in the ventrotemporal crescent of the retina, covering $20 \%$ of the retinal surface. Ipsilateral terminals are essentially clustered in the medial dLGN and in the SO and lower SGS of the SC. Contralateral projections to the SC originate from the entire retina (blue). Contralateral projections overlap with ipsilateral projections in the rostral SC (designated by an intermediate violet color) but not in the dLGN. $E$, Summary diagram of the transient localization of SERT observed in the present study. This includes data obtained by ISH in the retina, and SERT immunocytochemistry and high-affinity 5-HT uptake in the terminal fields. The area of SERT expression, shown in green, covers the periphery of the retina, excluding only the dorsalmost region. In the dLGN, SERT is present in the ipsilateral terminal field. In the SC, high-affinity uptake is present in the ipsilateral zones of the SO and lower SGS, but also in contralateral fibers innervating the top part of the SGS. 
target cells. Either of these proposed mechanisms could be important in correlating activity patterns between particular groups of afferent axons and their targets. In MAOA-KO mice, 5-HT concentrations, up to $800 \%$ higher than in wild-type animals (Cases et al., 1995) would overwhelm any control mechanisms based on local concentration of 5-HT.

The peripheral region of the retina in which we found SERT expression corresponds to the RGCs with the latest birth dates (Dräger, 1985; Reese and Colello, 1992) and that mature later (Reese et al., 1996). However, we do not believe that SERT expression simply reflects a developmental stage of RGC differentiation since SERT mRNA labeling remains restricted to this same peripheral region excluding the dorsal pole from E15 until P9. The territory of SERT expression partly overlaps with the ventrotemporal retinal crescent that contains the RGCs projecting ipsilaterally to the dLGN and the SC (Dräger and Olsen, 1980; Métin et al., 1983; Reese and Cowey, 1983). Although not all ipsilaterally projecting RGCs appeared to be labeled for SERT RNA (Fig. 9A), we did observe that SERT expression in the dLGN and the pretectal nuclei was mainly present in the ipsilateral terminal fields. However, in the SC high-affinity 5-HT uptake was detected in both ipsilateral and contralateral retinofugal projections. Since most RGCs provide collaterals to both the dLGN and the SC in adult albino rat (Yamadori et al., 1989), one would have expected to find SERT-positive retinal axons projecting contralaterally to both the SC and dLGN. Thus, either SERT is selectively expressed by the small population of RGCs that project only to the contralateral SC (13\% according to Yamadori et al., 1989), or it is targeted to one branch only of the bifurcating axons. However, because of technical limitations of our approach, we cannot exclude the possibility that SERT is present in the contralateral retinal projections to the dLGN: 5-HT uptake methods, which proved to be more sensitive than SERT immunoreactivity in localizing RGC axons, could not be used in the dLGN because this nucleus contains neurons that also express SERT during the same developmental period (Lebrand et al., 1996). Further investigations combining anterograde tracing and immunocytochemistry would be warranted to obtain a more precise description of this system.

\section{A general role for 5-HT in the establishment of topographic projections in the brain}

The influence of 5-HT on thalamic projections to the primary somatosensory (S1) cortex of rodents has been well documented. The cells of the ventrobasal nucleus of the thalamus that projects to the S1 cortex show a similar time course of expression of both SERT and VMAT2 to that observed in RGCs (Lebrand et al., 1996, 1998a), i.e., they are both expressed transiently during the period (E15-P10) when axons are growing into their target region and forming restricted projections patterns. Elevated 5-HT levels prevent the normal formation of barrels (Cases et al., 1996; Vitalis et al., 1998), whereas decreased levels of 5-HT delay the appearance of barrels (Blue et al., 1991; Osterheld-Haas et al., 1994) and cause them to be smaller (Bennett-Clarke et al., 1994).

There are several striking similarities between sensory thalamic neurons and peripheral RGCs: (1) both cell types are believed to be glutamatergic (Castel et al., 1993; Montero, 1994) and yet express SERT, VMAT, and 5-HT $\mathrm{HB}_{1 \mathrm{~B}}$ receptors during the critical period when axons are invading their targets and establishing their final topographical projection patterns (Bennett-Clarke et al., 1993; Lebrand et al., 1998b; and present study); (2) $5-\mathrm{HT}_{1 \mathrm{~B}}$ receptor agonists inhibit excitatory activity in both the thalamocortical and retinotectal projections (Mooney et al., 1994; Rhoades et al., 1994; Ropert et al., unpublished observations); (3) and finally, in both systems an excess of 5-HT disturbs the distribution of terminals into defined territories. Furthermore, other sensory thalamic nuclei that form topographic projection maps also express SERT, VMAT2, and 5- $\mathrm{HT}_{1 \mathrm{~B}}$ receptors during the first two postnatal weeks (Cases et al., 1998; Lebrand et al., 1998a,b), suggesting that these proteins might be involved in a common mechanism for the formation of restricted projections that is potentially influenced by 5 -HT. Studying the mechanisms of the action of 5-HT in pattern formation in one well-defined system, such as the retinal pathways, could help to unveil similar developmental mechanisms in other less well understood systems.

\section{REFERENCES}

Bennett-Clarke CA, Leslie MJ, Chiaia NL, Rhoades RW (1993) Serotonin $1 \mathrm{~B}$ receptors in the developing somatosensory and visual cortices are located on thalamocortical axons. Proc Natl Acad Sci USA 90:153-157.

Bennett-Clarke CA, Leslie MJ, Lane RD, Rhoades RW (1994) Effect of serotonin depletion on vibrissa-related patterns of thalamic afferents in the rat's somatosensory cortex. J Neurosci 14:7594-7607.

Bhide PG, Frost DO (1991) Stages of growth of hamster retinofugal axons: implications for developing axonal pathways with multiple targets. J Neurosci 11:485-504.

Blakely RD, Berson HE, Fremeau Jr RT, Caron MG, Peek MM, Prince HK, Bradley CC (1991) Cloning and expression of a functional serotonin transporter from rat brain. Nature 354:66-70.

Blue ME, Erzurumlu RS, Jhaveri S (1991) A comparison of pattern formation by thalamocortical and serotonergic afferents in the rat barrel-field cortex. Cereb Cortex 1:380-389.

Boulengez P, Pinard R, Segu L (1996) Subcellular localization of 5-HT binding sites in the stratum griseum superficiale of the rat superior colliculus: an electron microscopic quantitative autoradiographic study. Synapse 24:203-212.

Brüning G, Liangos O, Baumgarten HG (1997) Prenatal development of the serotonin transporter in mouse brain. Cell Tissue Res 289:211-221.

Bunin MA, Wightman RM (1998) Quantitative evaluation of 5-hydroxytryptamine (serotonin) neuronal release and uptake: an investigation of extrasynaptic transmission. J Neurosci 18:4854-4860.

Cases O, Seif I, Grimsby J, Gaspar P, Chen K, Pournin S, Müller U, Aguet M, Babinet C, Shih JC, De Maeyer E (1995) Aggressive behavior and altered amounts of brain serotonin and norepinephrine in mice lacking MAOA. Science 268:1763-1766.

Cases O, Vitalis T, Seif I, De Maeyer E, Sotelo C, Gaspar P (1996) Lack of barrels in the somatosensory cortex of monoamine oxidase A deficient mice: role of excess serotonin during the critical period. Neuron 16:297-307.

Cases O, Lebrand C, Giros B, Vitalis T, De Maeyer E, Caron GC, Price DJ, Gaspar P, Seif I (1998) Plasma membrane transporters of serotonin, dopamine, and norepinephrine mediate serotonin accumulation in atypical locations in the developing brain of monoamine oxidase A knockouts. J Neurosci 18:6914-6927.

Castel M, Belenky M, Cohen S, Ottersen OP, Storm-Mathisen J (1993) Glutamate-like immunoreactivity in retinal terminals of the mouse suprachiasmatic nucleus. Eur J Neurosci 5:368-381.

Cheng HJ, Nakamoto M, Bergemann AD, Flanagan JG (1995) Complementary gradients in expression and binding of ELF-1 and Mek4 in development of the topographic retinotectal projection map. Cell 82:371-381.

Colello RJ, Guillery RW (1990) The early development of retinal ganglion cells with uncrossed axons in the mouse: retinal position and axonal course. Development 108:515-523.

Crissman RS, Arce EA, Bennett-Clarke CA, Mooney RD, Rhoades RW (1993) Reduction in the percentage of serotoninergic axons making synapses during the development of the superficial layers of the hamster's superior colliculus. Dev Brain Res 75:131-135.

Dinopoulos A, Dori I, Parnavelas JG (1995) Serotonergic innervation of the lateral geniculate nucleus of the rat during development: a light and 
electron microscopic immunocytochemical analysis. J Comp Neurol 363:532-544.

Dooley AE, Pappas IS, Parnavalas JG (1997) Serotonin promotes the survival of cortical glutamatergic neurons in vitro. Exp Neurol 148:205-214.

Dräger UC (1985) Birth dates of retinal ganglion cells giving rise to crossed and uncrossed optic projections in the mouse. Proc R Soc Lond B Biol Sci 224:57-77.

Dräger UC, Olsen JF (1980) Origins of crossed and uncrossed retinal projections in pigmented and albino mice. J Comp Neurol 191: 383-412.

Drescher U, Kremoser C, Handwerker C, Làschinger J, Noda M, Bonhoeffer F (1995) In vitro guidance of retinal ganglion cell axons by RAGS, a $25 \mathrm{kDa}$ tectal protein related to ligands for Eph receptor tyrosine kinases. Cell 82:359-370.

Edwards MA, Schneider GE, Caviness VS (1986) Development of the crossed retinocollicular projection in the mouse. J Comp Neurol 248:410-421.

Fawcett JW, O'Leary DDM, Cowan WM (1984) Activity and the control of ganglion cell death in the retina. Proc Natl Acad Sci USA 81:5589-5593.

Feldheim DA, Vanderhaeghen P, Hansen MJ, Frisén J, Qiang L, Barbacid M, Flanagan JG (1998) Topographic guidance labels in a sensory projection to the forebrain. Neuron 21:1303-1313.

Galli L, Maffei L (1988) Spontaneous impulse activity of rat ganglion cells in prenatal life. Science 242:90-91.

Godement P (1994) Retinal axon divergence in the optic chiasm: dynamics of growth cone behavior at the midline. J Neurosci 14:7024-7039.

Godement P, Salaün J, Imbert M (1984) Prenatal and postnatal development of retinogeniculate and retinocollicular projections in the mouse. J Comp Neurol 230:552-575.

Godement P, Vanselow J, Thanos S, Bonhoeffer F (1987) A study in developing visual systems with a new method of staining neurones and their processes in fixed tissue. Development 101:697-713.

Goldberg JI, Mills LR, Kater SB (1991) Novel effects of serotonin on neurite outgrowth in neurons cultured from embryos of Heliosoma trivolvis. J Neurobiol 22:182-194.

Hahm JO, Langdon RB, Sur M (1991) Disruption of retinogeniculate afferent segregation by antagonists to NMDA receptors. Nature 351:568-570.

Hellendall RP, Schambra U, Liu JP, Lauder JM (1993) Prenatal expression of 5-HT1C and 5-HT2 receptors in the central nervous system. Exp Neurol 120:186-201.

Hoyer D, Clarke DE, Fozard JR, Hartig PR, Martin GR, Mylecharane EJ, Saxena PR, Humphrey PPA (1994) International Union of Pharmacology classification of receptors for 5-hydroxytryptamine (Serotonin). Pharmacol Rev 46:157-203.

Huang X, Mooney RD, Rhoades RW (1993) Effects of serotonin on retinotectal-, corticotectal-, and glutamate- induced activity in the superior colliculus of the hamster. J Neurophysiol 70:723-732.

Insausti R, Blakemore C, Cowan WM (1984) Ganglion cell death during development of ipsilateral retino-collicular projection in golden hamster. Nature 308:362-365.

Jeffery G (1984) Retinal ganglion cell death and terminal field retraction in the developing rodent visual system. Dev Brain Res 13:81-96.

Katz LC, Shatz CJ (1996) Synaptic activity and the construction of cortical circuits. Science 274:1133-1138.

Koe BK, Weissman A (1966) p-Chlorophenylalanine: a specific depletor of brain serotonin. J Pharmacol Exp Ther 154:499-516.

Krejci E, Gasnier B, Botton D, Isanbert MF, Sagne C, Gagnon J, Massoulie J, Henry JP (1993) Expression and regulation of the bovine vesicular monoamine transporter gene. FEBS Lett 335:27-32.

Land PW, Lund RD (1979) Development of the rat's uncrossed retinotectal pathway and its relation to plasticity studies. Science 205:698-700.

Land PW, Rose LL (1985) Exogenous monoamines affect the segregation of retinogeniculate fibres in developing rats. Dev Brain Res 22:135-140.

Lauder JM (1993) Neurotransmitters as growth regulatory signals: role of receptors and second messengers. Trends Neurosci 16:233-239.

Lavail JH, Nixon RA, Sidman RL (1978) Genetic control of retinal ganglion cell projections. J Comp Neurol 182:399-421.

Lebrand C, Cases O, Aldebrecht C, Doye A, Alvarez C, El-Mestikawy S, Seif I, Gaspar P (1996) Transient uptake and storage of serotonin in developing thalamic neurons. Neuron 17:823-835.
Lebrand C, Cases O, Wehrlé R, Blakely R, Edwards RH, Gaspar P (1998a) Transient developmental expression of monoamine transporters in the rodent forebrain. J Comp Neurol 401:506-524.

Lebrand C, Ezan P, Gaspar P (1998b) Developmental time course of the serotonin $1 \mathrm{~B}$ receptor expression in mouse thalamus. Eur J Neurosci 10 [Suppl] 10:407.

Lidov HGW, Molliver ME (1982) An immunohistochemical of serotonin neuron development in the rat: ascending pathways and terminal fields. Brain Res Bull 8:389-430.

Lotto B, Upton L, Price D, Gaspar P (1999) 5-HT receptor activation enhances neurite outgrowth of thalamic neurones. Neurosci Lett, in press.

Meister M, Wong ROL, Baylor DA, Shatz CJ (1991) Synchronous bursts of action potentials in ganglion cells of the developing mammalian retina. Science 252:939-943.

Métin C, Godement P, Saillour P, Imbert M (1983) Etude physiologique et anatomique des projections rétinogéniculées chez la souris. C R Acad Sci Paris 296:157-162.

Montero VM (1994) Quantitative immunogold evidence for enrichment of glutamate but not aspartate in synaptic terminals of retinogeniculate, geniculo-cortical, and cortico-geniculate axons in the cat. Vis Neurosci 11:675-681.

Mooney RD, Shi MY, Rhoades RW (1994) Modulation of retinotectal transmission by presynaptic $5-\mathrm{HT}_{1 \mathrm{~B}}$ receptors in the superior colliculus of the adult hamster. J Neurophysiol 72:3-13.

Mooney R, Penn AA, Gallego R, Shatz CJ (1996) Thalamic relay of spontaneous retinal activity prior to vision. Neuron 17:863-874.

Mooney RD, Crnko-Hoppenjans TA, Ke M, Bennett-Clarke CA, Lane R, Chiaia NL, Rhoades RW (1998) Augmentation of serotonin in the developing superior colliculus alters the normal development of the uncrossed retinotectal projection. J Comp Neurol 393:84-92.

Osterheld-Haas MC, Van der Loos H, Hornung JP (1994) Monoaminergic afferents to cortex modulate structural plasticity in the barrelfield of the mouse. Dev Brain Res 77:189-202.

Pazos A, Cortes R, Palacios JM (1985) Quantitative autoradiographic mapping of serotonin receptors in the rat brain. II. Serotonin-2 receptors. Brain Res 346:231-249.

Penn AA, Riquelme PA, Feller MB, Shatz CJ (1998) Competition in retinogeniculate patterning driven by spontaneous activity. Science 279:2108-2112.

Qian Y, Melikian HE, Rye DB, Levey AI, Blakely RD (1995) Identification and characterization of antidepressant-sensitive serotonin transporter proteins using site-specific antibodies. J Neurosci 15:1261-1274.

Reese BE, Colello RJ (1992) Neurogenesis in the retinal ganglion cell layer of the rat. Neuroscience 46:419-429.

Reese BE, Cowey A (1983) Projection lines and the ipsilateral retinogeniculate pathway in the hooded rat. Neuroscience 10:1233-1247.

Reese BE, Johnson PT, Baker GE (1996) Maturational gradients in the retina of the ferret. J Comp Neurol 375:252-273.

Rhoades RW, Bennett-Clarke CA, Lane RD, Leslie MJ, Mooney RD (1993) Increased serotoninergic innervation of the hamster's superior colliculus alters retinotectal projections. J Comp Neurol 334: 397-409.

Rhoades RW, Bennett-Clarke CA, Shi MY, Mooney RD (1994) Effects of 5-HT on thalamo-cortical synaptic transmission in the developing rat. J Neurophysiol 72:2438-2450.

Sachs GM, Jacobson M, Caviness VS (1986) Postnatal changes in arborisation patterns of murine retinocollicular axons. J Comp Neurol 246:395-408.

Shatz CJ (1990) Impulse activity and the patterning of connections during CNS development. Neuron 5:745-756.

Shatz CJ, Stryker MP (1988) Prenatal tetrodotoxin infusion blocks segregation of retinogeniculate afferents. Science 242:87-89.

Sidman RL, Green MC (1965) Retinal degeneration in the mouse: location of the rd locus in linkage group XVII. J Heredity 56:23-29.

Simon DK, O'Leary DDM (1992) Development of topographic order in the mammalian retinocollicular projection. J Neurosci 12:12121232.

So KF, Schneider GE, Frost DO (1978) Postnatal development of retinal projections to the lateral geniculate body in Syrian hamsters. Brain Res 142:343-352.

So KF, Campbell G, Lieberman AR (1990) Development of the mam- 
malian retinogeniculate pathway: target finding, transient synapses and binocular segregation. J Exp Biol 153:85-104.

Thompson ID, Holt CE (1989) Effects of intraocular tetrodotoxin on the development of the retinocollicular pathway in syrian hamster. J Comp Neurol 282:371-388.

Thompson ID, Cordery P, Holt CE (1995) Postnatal changes in the uncrossed retinal projection of pigmented and albino syrian hamsters and the effects of monocular enucleation. J Comp Neurol 357:181-203.

Vanhatalo S, Soinila S (1994) Pharmacological characterization of serotonin synthesis and uptake suggest a false transmitter role for serotonin in the pituitary intermediate lobe. Neurosci Res 21:143-149.

Vitalis T, Cases O, Callebert J, Launay JM, Price DJ, Seif I, Gaspar P (1998) Effects of monoamine oxidase A inhibition on barrel formation in the mouse somatosensory cortex: determination of a sensitive developmental period. J Comp Neurol 393:169-184.

Vizuete ML, Venero JL, Traiffort E, Vargas C, Machado A, Cano J (1997) Expression of 5-HT7 receptor mRNA in rat brain during postnatal development. Neurosci Lett 227:53-56.

Voigt MM, Laurie DJ, Seeburg PH, Bach A (1991) Molecular cloning and characterization of a rat brain cDNA encoding a 5-hydroxytryptamine 1B receptor. EMBO J 10:4017-4023.

Williams RW, Strom RC, Rice DS, Goldowitz D (1996) Genetic and environmental control of variation in retinal ganglion cell number in mice. J Neurosci 16:7193-7205.

Yamadori T, Nakamura T, Takami K (1989) A study of the retinal ganglion cell which has an uncrossed bifurcating axon in the albino rat. Brain Res 48:143-148. 